02 Royal Netherlands Institute for Sea Research

This is a postprint of:

Gollner, S.; Kaiser, S.; Menzel, L.; Jones, D.O.B.; Brown, A.; Mestre, N.C.; van Oevelen, D.; Menot, L.; Colaço, A.; Canals, M.; Cuvelier, D.; Durden, J.M.; Gebruk, A.; Egho, G.A.; Haeckel, M.; Marcon, Y.; Mevenkamp, L.; Morato, T.; Pham, C.K.; Purser, A.; Sanchez-Vidal, A.; Vanreusel, A.; Vink, A. \& Arbizu, P.M. (2018). Resilience of benthic deep-sea fauna to mining activities. Marine Environmental Research, 129, 76-101

Published version: https://dx.doi.org/10.1016/j.marenvres.2017.04.010

Link NIOZ Repository: $\underline{w w w . v l i z . b e / i m i s ? \text { module }=\text { ref\&refid }=289060}$

[Article begins on next page]

The NIOZ Repository gives free access to the digital collection of the work of the Royal Netherlands Institute for Sea Research. This archive is managed according to the principles of the Open Access Movement, and the Open Archive Initiative. Each publication should be cited to its original source - please use the reference as presented.

When using parts of, or whole publications in your own work, permission from the author(s) or copyright holder(s) is always needed. 


\section{Resilience of benthic deep-sea fauna to mining activities}

Sabine Gollner a, b, ", Stefanie Kaiser ${ }^{a}$, Lena Menzel a, Daniel O.B. Jones ${ }^{c}$, Alastair Brown ${ }^{d}$, Nelia C. Mestre ${ }^{e}$, Dick van Oevelen ${ }^{f}$, Lenaick Menot ${ }^{g}$, Ana Colaço ${ }^{h, i}$, Miquel Canals ${ }^{j}$, Daphne Cuvelier ${ }^{\mathrm{h}}$, i, Jennifer M. Durden ' , Andrey Gebruk ${ }^{k}$, Great A. Egho ', Matthias Haeckel ${ }^{\mathrm{m}}$, Yann Marcon ${ }^{n, o}$, Lisa Mevenkamp ', Telmo Morato ${ }^{\mathrm{h}, \mathrm{i}}$, Christopher K. Pham ${ }^{\mathrm{h}}$, ${ }^{\mathrm{i}}$, Autun Purser ${ }^{\mathrm{n}}$, Anna Sanchez-Vidal ${ }^{j}$, Ann Vanreusel ', Annemiek Vink ${ }^{\mathrm{P}}$, Pedro Martinez Arbizu ${ }^{\mathrm{a}}$

a German Centre for Marine Biodiversity Research (DZMB), Senckenberg am Meer, Wilhelmshaven, Germany

b Royal Netherlands Institute for Sea Research (NIOZ), Ocean Systems (OCS), 't Horntje (Texel), The Netherlands

${ }^{c}$ National Oceanography Centre (NOC), University of Southampton Waterfront Campus, Southampton, United Kingdom

d University of Southampton, Ocean and Earth Science, National Oceanography Centre Southampton, Southampton, United Kingdom

e CIMA, Faculty of Science and Technology, University of Algarve, Portugal

${ }^{f}$ Royal Netherlands Institute for Sea Research (NIOZ), Estuarine and Delta Systems (EDS), Yerseke, The Netherlands

${ }^{9}$ IFREMER, Institut français de recherche pour l'exploitation de la mer, Plouzane, France

h IMAR Department of Oceanography and Fisheries, Horta, Açores, Portugal

'MARE Marine and Environmental Sciences Centre Universidade dos Açores, Departamento de Oceanografia e Pescas, Horta, Açores, Portugal

${ }^{j}$ GRC Marine Geosciences, Department of Earth and Ocean Dynamics, Faculty of Earth Sciences, University of Barcelona, Barcelona, Spain

${ }^{k}$ P.P. Shirshov Institute of Oceanology, Moscow, Russia

' Marine Biology Research Group, Ghent University, Ghent, Belgium

m GEOMAR, Kiel, Germany

${ }^{\mathrm{n}}$ Alfred Wegener Institute (AWI), Bremerhaven, Germany

- MARUM Center for Marine Environmental Sciences, Bremen, Germany

${ }^{p}$ Bundesanstalt für Geowissenschaften und Rohstoffe, Hannover, Germany

* Corresponding author. German Centre for Marine Biodiversity Research (DZMB), Senckenberg am Meer, Wilhelmshaven, Germany.

E-mail addresses: sabine.gollner@nioz.nl, sabine.gollner@senckenberg.de (S. Gollner), stefanie.kaiser@senckenberg.de (S. Kaiser), lena.menzel@senckenberg.de (L. Menzel), dj1@noc.ac.uk (D.O.B. Jones), Alastair.Brown@noc.soton.ac.uk (A. Brown), ncmestre@ualg.pt (N.C. Mestre), Dick.van.Oevelen@nioz.nl (D. van Oevelen), Imenot@ifremer.fr (L. Menot), maria.aa.colaco@uac.pt (A. Colaço), miquelcanals@ub.edu (M. Canals), daphne.cuvelier@gmail.com (D. Cuvelier), jennifer.durden@noc.soton. ac.uk (J.M. Durden), agebruk@gmail.com (A. Gebruk), Egho.Great@UGent.be (G.A. Egho), mhaeckel@geomar.de (M. Haeckel), ymarcon@marum.de, yann.marcon@awi.de (Y. Marcon), Lisa.Mevenkamp@UGent.be (L. Mevenkamp), t.morato@gmail.com (T. Morato), phamchristopher@uac.pt (C.K. Pham), autun.purser@awi.de (A. Purser), annasanchezvidal@ub.edu (A. Sanchez-Vidal), Ann.Vanreusel@UGent.be (A. Vanreusel), Annemiek.Vink@bgr.de (A. Vink), pmartinez@senckenberg.de (P. Martinez Arbizu).

Keywords: Deep ocean; Disturbance; Minerals; Mining; Abyssal plains; Hydrothermal vents Seamounts; Resilience; Recovery; Benthos 


\begin{abstract}
With increasing demand for mineral resources, extraction of polymetallic sulphides at hydrothermal vents, cobalt-rich ferromanganese crusts at seamounts, and polymetallic nodules on abyssal plains may be imminent. Here, we shortly introduce ecosystem characteristics of mining areas, report on recent mining developments, and identify potential stress and disturbances created by mining. We analyze species' potential resistance to future mining and perform meta-analyses on population density and diversity recovery after disturbances most similar to mining: volcanic eruptions at vents, fisheries on seamounts, and experiments that mimic nodule mining on abyssal plains. We report wide variation in recovery rates among taxa, size, and mobility of fauna. While densities and diversities of some taxa can recover to or even exceed pre-disturbance levels, community composition remains affected after de- cades. The loss of hard substrata or alteration of substrata composition may cause substantial community shifts that persist over geological timescales at mined sites.
\end{abstract}

\title{
Contents
}

1.Introduction

2.Materials and methods

3.Ecosystem characteristics

3.1.Polymetallic sulphides, active and inactive hydrothermal vents

3.1.1. Minerals and physical environment

3.1.2.Biological communities at active and inactive vents and in the vent periphery

3.2.Cobalt-rich ferromanganese crusts, seamounts

3.2.1.Minerals and physical environment

3.2.2.Biological communities at seamounts with and without crusts

3.3.Polymetallic nodules, abyssal plains

3.3.1.Minerals and physical environment

3.3.2.Biological communities on nodules and in deep-sea sediments

4.Mineral mining

4.1.Licencing in international and national waters

4.2. Mineral mining operations

4.3.Mining threats

5.Estimating resilience of deep-sea ecosystems

5.1Resistance

5.2. Recovery after small-scale disturbance events

5.2.1. Hydrothermal vents

5.2.2. Seamounts

5.2.3.Nodule fields

5.3. Reversibility after mineral mining impacts

5.3.1. Hydrothermal vents and polymetallic sulphides

5.3.2. Seamounts

5.3.3. Nodule fields

5.3.4.Areas adjacent to mining sites

6.Conclusion

Contributions

Declaration of interest

Acknowledgments

Supplementary data

References 


\section{Introduction}

Resilience represents a key concept in ecosystem response to disturbance effects. It can be defined as the ability of a system to maintain its overall identity, i.e. the same function and structure, in the face of internal change and external perturbations (Cumming et al., 2012; Holling, 1973; Walker et al., 2004). Resilience relates to a number of processes (Levin, 1999; Levin and Lubchenco, 2008; Palumbi et al., 2008): (1) resistance, as the amount of stress and disturbance that can be absorbed by a system before processes controlling the structure and function of a system change (Gunderson, 2000), (2) recovery, as the rate an ecosystem returns to pre-disturbance conditions after an disturbance event (Lotze et al., 2011), and (3) reversibility, as whether processes are reversible (Lotze et al., 2011) and if the system is capable returning to the original condition after change (Palumbi et al., 2008). Ecosystems that pass a critical threshold or tipping point, marking a drastic change in ecosystem function, are putatively unlikely to recover to the original state (Lotze et al., 2011; Lees et al., 2006; Suding et al., 2004).

With increasing interest of companies and countries in deep-sea mining, it is crucial to evaluate the resilience of deep-sea ecosystems to mining disturbance, and thus to assess the potential ecological consequences of extracting mineral resources from the deep-sea floor. Three different types of deep-sea mineral resources are being granted for exploration licenses: polymetallic sulphides on active and inactive hydrothermal vents, cobalt-rich ferromanganese crusts on seamounts, and polymetallic nodules on abyssal plains. Targeted ecosystems support different types of biological communities that may be differently impacted from mining activities. Mining activities will impose disturbances with novel nature, strength, stability and spatial and temporal scale on deep-sea ecosystems (Van Dover, 2014; RamirezLlodra et al., 2011; Oebius et al., 2001; Glover and Smith, 2003; Leduc et al., 2015; Boschen et al., 2013; Van Dover, 2011; SPC, 2013; SPC, 2013; SPC,2013; Clark and Smith, 2013).

In this review, we aim to evaluate the potential resilience of benthic deep-sea fauna to mining activities at hydrothermal vents, seamounts and abyssal plains. We first set the scene by shortly introducing ecosystem characteristics, recent mining de- velopments, and potential stress and disturbances created by mining. In particular, we (1) estimate to what extent targeted ecosystems may be resistant to mining disturbance, (2) review known recovery rates to small-scale disturbance events that are considered most similar to future mining disturbance (volcanic eruptions at hydrothermal vents; fisheries at seamounts; disturbance experiments designed to mimic nodule mining on abyssal plains), and (3) relate this knowledge (and knowledge gaps identified) to potential reversibility of ecosystem change following mineral mining disturbance.

\section{Materials and methods}

The study is based on literature review, as well as meta-analyses of empirical and long-term quantitative data assessing the recovery of deep-sea fauna communities following natural or anthropogenic disturbances. For meta-data analyses, we identified impacts most similar to future mining events as: (1) volcanic eruptions that locally eliminate entire communities at hydrothermal vents, (2) bottom-trawl fisheries on seamounts, and (3) disturbance experiments designed to mimic nodule mining at nodule fields on abyssal plains. For the meta-data analyses we included only studies where duration between initial disturbance and postdisturbance measurements was known. When pre-disturbance measurements were unavailable, measurements from close proximity reference areas (control) were used instead (see Appendix A). Percent recovery was plotted against time elapsed since the disturbance impact using the program $R$ (Hornik, 2009). Datasets where the pre-disturbance value was zero, i.e. the respective taxon had not been sampled, are discussed in the manuscript, but were excluded from the analyses. 
Faunal responses to disturbances reported in the literature are presented in Appendix A, identifying ecosystem type, geographic region, type of impact, comparable potential mining impact, scale of impact, response category (density or diversity), type of response measured (e.g. species richness S, Shannon-diversity $\mathrm{H}^{\prime}$ ), taxonomy information (phylum, class, order, family, genus, species), size class (meio-, macro-, megafauna), and mobility (mobile, sessile). The results of the literature search and specific meta-analysis for nodule systems are reported in more detail in Jones et al. (2017). Mobility was included in the analyses as it may be linked to species connectivity and thus recovery potential (Correa et al., 2016). Size classes were used in the analyses since meio-, macro- and mega-fauna communities influence and depend on each other (O' lafsson,2003), and recent studies have shown that different sized organisms may respond differently to stress and disturbance (Gollner et al., 2015a,b). We followed the definition of size-classes used in original articles. Megafauna typically included large animals seen with the unaided eye or are visible in seabed photographs. At hydrothermal vents, where fauna is typically large, (adult) macro- fauna was classified as fauna larger $1 \mathrm{~mm}$, with no further discrimination into mega- and macrofauna. On nodule fields, where macrofauna is typically small, macrofauna included organ- isms retained on a $500 \mathrm{~mm}$ mesh sieve. Meiofauna was typically classified as fauna smaller than $1 \mathrm{~mm}$. The lower mesh-size used varied from 32 to $63 \mathrm{~mm}$ (older studies typically used $63 \mathrm{~mm}$ ). However, Ingole et al. (2001) classified all fauna in deep-sea sediments (including nematodes and copepods) as macrofauna, but we reclassified typical meiofauna taxa (nematodes, copepods) as meiofauna.

Since the nature of measurements, the number of samples, and sampling technique was often substantially different across studies, we calculated mean percent recovery following a specified period (in years) for each study (Appendix A). Calculation of mean percent recovery was based on mean original values of pre-disturbance conditions and the mean (experimental) values measured post- impact (100 x after disturbance / pre disturbance). To account for variability, original values for pre- and post-disturbance and their standard deviation are provided whenever possible in Appendix A and in figures, and are discussed. Mean values of pre-disturbance conditions were interpreted as representing $100 \%$ of the original densities or diversities. Consequently, $50 \%$ density recovery after one year would imply that mean density value was half the pre- disturbance value one year after disturbance, and $200 \%$ density recovery after one year would imply that mean density value was double the pre-disturbance value one year after disturbance.

To unravel large scale underlying patterns of recovery in the three different ecosystem types, we tested for differences in mean percent recovery for diversity and density between organism size-classes (meio-, macro-, megafauna), mobilities (sessile, mobile), and localities using the one-sided Wilcoxon rank sum test (Wilcoxon, 1945). The non-parametric one-sided Wilcoxon rank sum test tests for differences between each set of pairs of two paired groups, assuming that values of one of the paired groups are larger than the other. The BenjaminiHochberg correction was used to account for the number of possible comparisons in order to control the expected proportion of false discoveries (Benjamini and Hochberg, 1995). Whilst these analyses may identify potential large scale trends in species recovery they cannot account for variability within samples. Where mobility of study organisms comprised mobile as well as sessile taxa, mobility was defined as "mixed", and data were excluded from mobility analyses.

\section{Ecosystem characteristics}

\subsection{Polymetallic sulphides, active and inactive hydrothermal vents}

\subsubsection{Minerals and physical environment}

Polymetallic sulphides (Fig. 1 a), also referred to as seafloor massive sulphides (SMS), form on or below the seabed where hydrothermal vents release mineralized seawater (Von Damm, 2004; Fisher et al., 2007; Von Damm, 1995). Minerals in hydrothermal fluids precipitate when they come into contact with cold seawater, and form chimney structures (Fig. 2 a) and/or 
disperse with the hydrothermal plume through the water. Deposits are patchily distributed at mid-ocean ridges, in back-arc basins, and along submarine volcanic arcs (seamounts). The abundance and content of sulphides differs between fast- and slow-spreading ridges; whilst lavas commonly disrupt the flow of hydrothermal fluids and bury sulphide deposits every decades at fast spreading ridges (e.g. the East Pacific Rise, EPR), eruptions occur on intervals of thousands of years and deposits are of larger scale at slow spreading ridges (e.g. the Mid Atlantic Ridge (MAR), the Central Indian Ridge (CIR)) (Boschen et al., 2013; SPC, 2013).

The mineral-rich hydrothermal fluids range in temperature from just a few degrees Celsius to $>400^{\circ} \mathrm{C}$ (Von Damm, 2004; Fisher et al., 2007). Local fluid flows at active hydrothermal vent sites can reduce and stop within a few months at fast-spreading ridges such as the EPR (Klose et al., 2015) or can be stable for de- cades on slow-spreading ridges such as the MAR (Cuvelier et al., 2011). Vent chimneys and edifices can be several tens of metres high and are commonly inhabited by specialised communities (Van Dover, 2011). The stability at individual sites as well as vent fields exerts a strong influence on the largely endemic megaand macrofauna that are dependent on rich in situ primary production by sulphide- and methane oxidizing bacteria (Van Dover, 2000).

\subsubsection{Biological communities at active and inactive vents and in the vent periphery}

Fauna associated with polymetallic sulphides at active hydro- thermal vents (Fig. 2 a, b) are fueled by rich in situ primary production generated via chemosynthesis. Many mega- and macrofaunal groups have evolved complex physiological or behavioral adaptations to the extreme environmental conditions in vent habitats (Childress and Fisher, 1992; Rinke and Lee, 2009; Bates et al., 2010). Dominant symbiotrophic megafauna include mussels, snails, shrimps and polychaetes, whereas dominant macrofauna taxa include limpets, crabs, amphipods and polychaetes (Van Dover, 2000). Whilst these fauna are typically abundant with high biomass, species richness is low (Grassle, 1985). Mega- and macrofauna show a high level of endemism in biogeographic provinces at both species (95\%) and generic level $(76 \%)$ (Moalic et al., 2012). Furthermore, the mega- and macrofauna are commonly endemic to the active vent environment (Tunnicliffe, 1992). In contrast to the macrofauna, meiofauna are not exceptionally abundant at the vents, but meiofauna and macrofauna show similar species richness (Gollner et al., 2015b; Copley et al., 2007a; Cuvelier et al., 2014; Plum et al., 2017). However, vent meiofauna species also occur in the vent periphery, with few species restricted to the vents (Gollner et al., 2010). Since vents are patchy, transient, and often separated by tens to hundreds of kilometers, connectivity among invertebrate populations is through larval dispersal (Gollner et al., 2015a; Mullineaux et al., 2010; Breusing et al., 2015; Boschen et al., 2016b).

Fauna associated with polymetallic sulphides at inactive vents (Fig. 2 c) are little known. Consequently, it is largely unclear whether assemblages that thrive at inactive vents are similar to active vent fauna, are similar to fauna inhabiting hard substrata on non-mineral rich grounds, or are unique (Van Dover, 2011). Inactive chimney structures provide substratum for benthic suspension feeders and typically host sponges and cnidarians (Boschen et al., 2015; Galkin, 1997; Levin et al., 2016a; Boschen et al., 2016a). Some macrofauna and nematode species from active vent sites are also observed at inactive vent sites (Gollner et al., 2013; Levin et al., 2009). A comparative study of an active hydrothermal seamount, an inactive hydrothermal seamount with polymetallic sulphides, and a seamount without hydrothermal activity and without mineral deposits, revealed that magnetivity, as a proxy for hydrothermal activity, explained the majority of the variation in megafauna assemblage structures present at the three seamounts (Boschen et al., 2015).

There is a paucity of data on fauna from the vent periphery (also termed vent proximate areas, or vent background) but fauna appears to vary with region. Vent peripheral megafauna on the MAR consist of sessile, filter-feeding, long-lived and slow-growing taxa such as sponges, corals and deep-sea crabs (Galkin, 1997; Tempera et al., 2013; Colaço et al., 1998) (Fig. 2 d). Peripheral areas near the Eiffel Tower (Lucky Strike vent field) have high diversity, e.g. of copepods, and also harbour several copepod species typical for active vents. Additionally, juvenile vent fauna have been observed in the vent periphery (Plum et al., 2017). 
Similarly, vent-peripheral areas on the 9oN EPR support juveniles of macrofauna typical of the vent environment, as well as a diverse meiofauna community (Gollner et al., 2015b). Ventperipheral macrofauna communities in the Lau Basin are largely distinct from active vent communities, with few vent endemic species present (Collins et al., 2012). Peripheral macrofaunal communities at Eastern Lau Spreading Center and Valu Fa Ridge (ELSCVFR) harbour mainly zoanthids, anemones, symbiont-containing mussels, brisingid seastars, and polynoids at the northern peripheral sites, whereas sponges, pycnogonids and ophiuroids dominate at southern peripheral sites. Taxonomic richness in these vent-peripheral macrofauna communities is similar to that of active vent communities (Sen et al., 2016). In comparison, peripheral assemblages at Scotia Ridge in the Southern Ocean typically comprise asteroids and pycnogonids (Marsh et al., 2012).

\subsection{Cobalt-rich ferromanganese crusts, seamounts}

\subsubsection{Minerals and physical environment}

Cobalt-rich ferromanganese crusts (Fig. 1 b) are formed by the precipitation of metals dissolved in seawater, grow at rates of $1 \mathrm{e} 6 \mathrm{~mm}$ per million years, and can form thick pavements of up to $26 \mathrm{~cm}$ thickness (SPC, 2013; Hein, 2002; Hein and Petersen, 2013). These crusts typically form on exposed hard rock on seamounts, and especially on guyot plateaus with strong currents that prevent the accumulation of sediments. Seamounts are underwater mountains of volcanic origin, and hydrothermal venting may be associated with seamounts, making seamounts a target not only for crust mining but also for polymetallic sulphide mining (Boschen et al., 2016a). Approximately, $10000 \mathrm{e} 33,000$ seamounts are arrayed across the ocean floor (Kim and Wessel, 2011; Harris et al., 2014; Yesson et al., 2011). Like terrestrial mountains, seamounts exhibit a range of shapes and sizes. Geophysical characteristics of seamounts accelerate water currents, generate upwelling of nutrients, and create retention of water masses, thereby increasing local productivity and external flow of organic matter (Pitcher et al., 2007; Clark et al., 2010; Genin et al., 1986).

\subsubsection{Biological communities at seamounts with and without crusts}

Seamounts are considered to be hotspots of species richness (Morato et al., 2010). High productivity at seamounts supports relatively high biomass of demersal fish populations and large numbers of benthic filter feeders, such as corals and sponges (Fig. 2e) in comparison to adjacent deep continental margins at comparable depths (Rowden et al., 2010; Clark et al., 2011). However, there is little known about the seamount fauna in general, and about crustassociated fauna in particular (O'Hara and Tittensor, 2010; Schlacher et al., 2014; Grigg et al., 1987); few seamounts (<1\%) have been sampled (Clark et al., 2010; O'Hara and Tittensor, 2010). Furthermore, studies have focused on megafaunal organisms, with little information available on macro- and meiofauna (George, 2013; Zeppilli et al., 2014), or on microbiota.

Many seamount taxa are long-lived and slow-growing, especially those forming biogenic structures. Individuals of some species may be hundreds to thousands of years old: for example, it may take thousands of years for stony corals to build complex biogenic structures (Clark et al., 2016). Seamount faunas can vary greatly even at local (km) spatial scales (O'Hara and Tittensor, 2010; Schlacher et al., 2014; Clark et al., 2012). Variation in community composition and diversity has been related to a number of environmental factors, particularly those linked to depth and seabed structure (e.g. substratum, relief, presence of bio-constructors), as well as current regimes and distance to source populations, amongst others (Boschen et al., 2015; Clark et al., 2010; Schlacher et al., 2014).

Owing to a paucity of data, it remains uncertain whether fauna associated with crusts differs from similar non-crust areas (Schlacher et al., 2014; Grigg et al., 1987). However, Schlacher et al. (2014) and Morgan et al. (2015) identified differences in biodiversity and community structure between seamounts with and without crusts. Nonetheless, it remains unclear whether chemical components of the crusts are dominant drivers of benthic assemblage structure, or whether differences result from contrasting seafloor parameters, such as geographic location, topography and depth-related factors (Schlacher et al., 2014). 


\subsection{Polymetallic nodules, abyssal plains}

\subsubsection{Minerals and physical environment}

Polymetallic nodules, also referred to as manganese nodules, are potato-shaped concretions with a size range of $2-8 \mathrm{~cm}(\max .15 \mathrm{~cm}$ ) that are composed of manganese oxides and iron oxihydroxides (Fig. $1 \mathrm{c}$, Fig. 2 f). Polymetallic nodules grow with average rates of $10-20 \mathrm{~mm}$ per million years. They occur in high abundances on the sediment-covered abyssal plains of all oceans, where sedimentation rates are low $(<10 \mathrm{~mm} \mathrm{kyr}-1)$. Nodules are embedded in the sediment surface. Nodules therefore provide a hard substratum habitat on abyssal plains dominated by sediment. Deep-sea sediments around nodules typically consist of a mixture of siliceous ooze and deep-sea clay and are rich in oxygen (ISA,2010; Mewes et al., 2014; Müller et al., 1988). The environment is very stable, with low current velocities $(3.8 \pm 2.0 \mathrm{~cm} \mathrm{~s}-1)$ (Kuhn et al., 2015). Well-studied occurrences of manganese nodules are known from the Clarion Clipperton Fracture Zone (CCZ) in the NE equatorial Pacific, the Peru Basin in the SE Pacific, the Cook Island region in the SW Pacific, and in the Central Indian Ocean Basin (Hein and Koschinsky, 2013). The CCZ contains the largest known contiguous occurrence of nodule fields and covers an area of approximately 4 million square kilometers (an area as large as the European Union) (ISA, 2010). Nodule abundance in the CCZ ranges between 0 and $\sim 30 \mathrm{~kg}$ $\mathrm{m}-2$ (based on wet nodule weight) with an average of $15 \mathrm{~kg} \mathrm{~m}-2$ (SPC, 2013).

\subsubsection{Biological communities on nodules and in deep-sea sediments}

At higher taxonomic levels, the composition of the soft- sediment fauna around nodules resembles abyssal areas else- where. The dominant meiofaunal groups are nematodes, followed by harpacticoid copepods, whilst polychaetes and isopods are the dominant macrofaunal taxa. Typical megafaunal organisms include ophiuroids, holothurians, fish, large komokiaceans and xenophyophore protists (Ramirez-Llodra et al., 2010). Diversity can be high at both local and regional spatial scales (Janssen et al., 2015; Glover et al., 2002; Wang et al., 2010). Across the CCZ there are pronounced changes in species composition in some taxa such as polychaetes, isopods, and nematodes (Glover et al., 2002; Peterson et al., 1998; Janssen et al., 2015). Differences among samples are typically driven by a high proportion of rare species (defined as species with only few individuals occurring in samples and/or with a restricted geographical range) (Paterson et al., 2015).

Nodule surfaces are often covered with sessile organisms such as sponges, cnidarians and xenophyophores, but crevices are also inhabited by meiofauna, such as nematodes, harpacticoid copepods, tardigrades, and foraminiferan protists (Miljutin et al., 2010; Miljutina et al., 2010; Thiel et al., 1993; Veillette et al., 2007b). Nodule surface and adjacent soft sediment fauna are distinct in a number of protozoan and metazoan taxa (Thiel et al., 1993; Veillette et al., 2007a; Mullineaux, 1987; Dugolinsky et al., 1977). Epifaunal densities are higher in regions with dense nodule seafloor coverage, and epifauna such as alcyonacean and antipatharian corals are virtually absent in nodule-free areas (Vanreusel et al., 2016). Many larger epifaunal species appear to be widespread, but these distributions are based predominantly on morphological examination from video and/or still images which provide insufficient resolution for species-level identification. Nonetheless, recent analysis of nodule encrusting foraminiferans revealed that most morpho-species are widely distributed across the CCZ (Gooday et al., 2015). Remarkably little is known regarding the geographic distribution of the nodule associated fauna, such as whether species are unique to nodules or whether adjacent seamount crusts host these same species.

\section{Mineral mining}

\subsection{Licencing in international and national waters}


Many deep-sea mineral resources are found in areas beyond national jurisdiction i.e. "The Area" (>200 nautical miles offshore, depending on whether a state has an extended continental shelf), which are managed by the International Seabed Authority (ISA). Contractors may apply for a 15-year exploration contract at the ISA, which gives them exclusive rights to prospect for mineral resources in a specific exploration area. In the case of manganese nodules, a single exploration area covers up to $75000 \mathrm{~km} 2$ of seafloor (Fig. 3), but areas are smaller in the case of polymetallic sulphide or crust exploration comprising 3000 and $10000 \mathrm{~km} 2$, respectively (Weaver, 2016). Ocean-wide, 26 exploration contracts have been issued to date. In 2014 alone, the ISA approved seven new mineral exploration licences (https://www.isa.org.jm/deepseabed- minerals-contractors). The first six pioneer contractors ended their 15-year exploration period in 2016. These contractors have applied for exploration extensions for a further 5-year period. Subsequent to the exploration contract, nations/companies may apply for an exploitation licence.

Within the Exclusive Economic Zone (EEZ) of a country, mineral resources on the ocean floor are not managed by the ISA, but are instead managed by national regulation. Nations may grant exploration and exploitation licences to companies. Within EEZs, most exploration licenses for deep-sea minerals have been issued by island states in the SW Pacific, Japan, and New Zealand (SPC, 2013; Boschen et al., 2016a). Nautilus minerals, Bluewater Minerals (Nautilus subsidiary), Neptune Minerals, Bismarck (Neptune subsidiary), Diamond Fields International, Korea Institute of Ocean Science and Technology (KIOST), Japan Oil, Gas \& Metals National Corp (JOGMEC) have applied for or have been granted SMS or cobaltrich crust exploration licences in the South Pacific. The first exploitation license for polymetallic sulphides and for deep-sea minerals in general was granted by Papua New Guinea to the company Nautilus minerals in 2011. Approximately 10 ha are being considered for mining at Solwara1 (VanDover et al., 2014; Coffey Systems, 2008). Neptune Minerals has prospecting license applications and granted prospecting licenses covering $175000 \mathrm{~km} 2$ in the EEZ of Japan, Papua, New Guinea, Solomon Islands, Vanuatu, Fiji, Tonga and New Zealand (http://www.neptuneminerals.com/ our-business/tenements/).

\subsection{Mineral mining operations}

The anticipated mining disturbance varies greatly among the different mineral resources and their associated ecosystems. Mining operations will be conducted by machines operating at water depths down to several kilometers. Seabed crawlers for sulphide mining will have auxiliary cutters and bulk cutters to shred mineral deposits (Fig. 3 b) and also collecting machines (Fig. $3 \mathrm{c}$ ). The resulting rock mixture will be transported to a surface support vessel as a slurry by a riser and lifting system (Fig. $3 \mathrm{c}$ ). Similar conceptual plans exist for mining crusts (Fig. $3 \mathrm{~d}$ ). Machines for nodule collection are not yet available, but several concepts exist and prototypes have been built. Nodule-mining machines are proposed to plough tens of centimeters into the seafloor sediments, mechanically or hydraulically removing the nodules from the sediment. The nodule-sediment mixture will be transported to a surface support vessel as a slurry by a riser and lifting system, where the sediment will be separated from the nodules and returned to the water column through a discharge pipe (Lehmkoester, 2014) (Fig. 3 e). The nature of mining disturbance will also depend on the technology used, even for the same mineral type. For example, tools proposed for sulphide mining by Nautilus for Solwara 1 are less smothering than methods suggested by the Japan Deep Sea Technology Association (DESTA) (Boschen et al., 2013) (and references therein).

The potential size of mined areas may vary greatly among the different mineral resources. For each exploitation license issued by the ISA, nodules may be extracted from 300 to 800 square kilo- meters in a year of mining (Wedding et al., 2015; Smith et al., 2008) and 8500 square kilometers over a 20 year period (Van Dover, 2014; Boschen et al., 2013; Madureira et al., 2016; Hein et al., 2009). In contrast, Nautilus Minerals would target only 0.112 $\mathrm{km} 2$ of seabed during polymetallic sulphide mining at Solwara 1, although it could disrupt connectivity of hydrothermal habitat in the region (Boschen et al., 2013; Nautilus Minerals, 
2008). Some mining plans, such as those of Nautilus Minerals, propose a patchy removal strategy with a mixture of temporary and quasi- permanent refuge areas (Boschen et al., 2013).

\subsection{Mining threats}

Mining activities will impose disturbances with novel nature, strength, persistence, and spatial and temporal scale on deep-sea ecosystems. Direct mining impacts will include mortality and removal of fauna living on mined substrata, removal of substrata and habitat loss, habitat fragmentation, habitat modification (i.e. change of mineral and sediment composition, topography, chemical regimes), and diverse other direct impacts such as sound and electromagnetic radiation by mining instruments. Indirect impacts comprise the formation of (potentially toxic) sediment plumes by the activity of crawlers, seabed installations and risers, and potential release of toxic substances into the water column along the riser system and/or by process material discharged from the ship (return plume) (Van Dover, 2014; Ramirez-Llodra et al., 2011; Oebius et al., 2001; Glover and Smith, 2003; Leduc et al., 2015; Boschen et al., 2013; Van Dover, 2011; SPC, 2013; SPC, 2013; SPC,2013; Clark and Smith, 2013). Further details are discussed in the reversibility chapter (5.3).

\section{Estimating resilience of deep-sea ecosystems}

\subsection{Resistance}

To date, large-scale commercial mineral mining has not taken place. Very likely, the removal of minerals will kill fauna inhabiting mineral deposits. However, the capacity for populations of deep- sea species to stay essentially unchanged despite disturbances (resistance sensu (Grimm and Wissel, 1997)) associated with deep- sea mining remains uncertain. Resistance (natural ability to remain unaffected by a force) may apply to species response to sound/vibration and electromagnetic radiation produced by mining operations. Shallow-water marine mammals, fish, and invertebrates are physiologically sensitive to acoustic disturbance (Aguilar de Soto and Kight, 2016) with potential for ecological effects such as alteration in natural behaviour, reduction in communication ranges, reduction in foraging ability, prevention of predator avoidance, complete habitat avoidance, and death (Stanley and Jeffs, 2016; Burritt and Lamare, 2016). These physiological and behavioral effects can alter the ecology of marine systems (Moreau et al., 2016). However, the effects of these potential stressors on deep-sea fauna are poorly constrained: data on sound/vibration and/or electromagnetic radiation impact at deep-sea vents, sea- mounts or nodule fields are few and uninformative in a deep-sea mining context. For example, high-intensity illumination associated with Human-Occupied Vehicles (HOVs) and Remotely Operated Vehicles (ROVs) has been implicated in photoreceptor damage in shrimp that aggregate on black smokers at Mid-Atlantic Ridge vents (Van Dover, 2014). The structure and light-sensitive visual pigment (rhodopsin) of thoracic eyes in adult vent shrimp suggests that they are adapted to detecting the dim light generated by high- temperature venting as a near-field remote-sensing means of avoiding thermal stress and mortality. The initial description of these photoreceptors identified degradation inferred to result from light exposure (Van Dover et al., 1989) and it was suggested that cellular machinery to support recovery from light damage disappears during ontogeny (Chamberlain, 2000). The behavioral con- sequences of light-damaged photoreceptors in vent shrimp are unknown, but there is no evidence of impacts on shrimp populations repeatedly exposed to high-intensity illumination (Copley et al., 2007b). However, these shrimp populations are only intermittently exposed to high-intensity illumination, which may not be representative of exposures that will occur during mineral exploitation. Further, the significant variation in visual ecology among deep-sea taxa (Herring, 1990) is likely to influence resistance. Consequently, extrapolating resistance potential to radiation caused by deep-sea mineral exploitation processes to other taxa is not yet possible. 
Mining will produce sediment plumes on the sea floor, as well as producing discharge sediment plumes in the water column, following mineral washing and fractioning procedures on board of the support vessels. Plumes will disperse beyond the area of direct mining impact. The concept of resistance applies to communities living in these indirectly impacted areas that may cover larger areas than the directly mined area. Sulphide test mining at the Solwara 1 site off Papua New Guinea, indicated increased sedimentation (up to $500 \mathrm{~mm}$ ) within $1 \mathrm{~km}$ of the discharge site, with some material potentially dispersing up to $10 \mathrm{~km}$ away (Boschen et al., 2013; Nautilus Minerals, 2008). Natural sedimentation rates at vents are much lower, ranging for example from $\sim 1$ to $2 \mathrm{~mm}$ per year in Guaymas basin (Atkins et al., 2000) to $\sim 0.0025 \mathrm{e} 0.03$ $\mathrm{mm}$ per year at Juan de Fuca (Costa et al., 2016). On abyssal plains and sea- mounts, natural sedimentation rates are in the order of only several $\mathrm{mm}$ per thousand years (Petersen et al., 2016). Yet, it remains un- clear if and to what extent deep-sea communities may be resistant to particle plumes generated by mineral extraction and resus- pension of sediments.

Environmental impact assessment of the deep-water oil and gas exploitation industry indicates that both increased sedimentation and toxicant exposure have significant ecological effects that can extend to more than $5 \mathrm{~km}$ from the point source (see (Cordes et al., 2016) and references cited therein). However, impacts depend on both the magnitude and composition of the released material which differs significantly both within and between the deep-sea oil and gas industry and the deep-sea mineral industry, preventing direct inferences of resistance to deep-sea mining impacts.

Particle plumes generated by mineral mining may physically smother benthic organisms, clogging gas exchange and feeding structures (Cordes et al., 2016). Seafloor coverage by a $3 \mathrm{~mm}$ thick layer of drill cuttings can significantly affect infaunal communities (Schaaning et al., 2008). However, significant quantitative impacts on meiofaunal abundance and community composition have also been observed beyond the extent of observable drill cuttings deposition (Netto et al., 2009). Resistance to sedimentation generated by mineral extraction processes is likely to vary based on the ecology of individual species, for example depending on whether taxa are epifauna or infauna, errant or sessile, suspension feeders, filter feeders, deposit feeders, or necrophages (see (Cordes et al., 2016) and references cited therein).

Shifts in density, biomass, and diversity of benthic assemblages in response to offshore oil and gas exploitation have also been linked to increased toxicant concentrations (Breuer et al., 2004; Holdway, 2002; Santos et al., 2009; Trannum et al., 2010). However, sulfide mineral metal bioavailability and toxicity data are currently only available from laboratory studies with shallow- water fauna (Nautilus Minerals, 2008; Simpson and Spadaro, 2016), which may be unrepresentative of deep-adapted fauna (Mestre et al., 2014). Mineral particles have high metal concentrations and deep-sea sediments are typically metal enriched (Ramirez-Llodra et al., 2011). Metal concentrations present in mineral particle plumes appear less toxic than the corresponding concentration of dissolved metals (Simpson and Spadaro, 2016) thus the oxidation/reduction processes during mining operations will significantly affect toxicant bioavailability. Mineral dissolution rates depend on the composition of mineral deposits and are also sensitive to redox conditions (Knight and Roberts, 2016), therefore toxicant bioavailability will be site specific with spatial and temporal variability. Further, toxicant bioavailability may also be influenced by the ecology of individual species, depending on e.g. whether taxa are epifauna or infauna, errant or sessile, suspension feeders, filter feeders, deposit feeders, or necrophages (McLusky et al., 1986). For example, the ability of species to tolerate (and resist) potentially toxic particles is likely higher at active vents, which are already under the influence of the putatively toxic hydrothermal fluid and plumes (Childress and Fisher, 1992), than at inactive vents and in the wider deep sea, where taxa are not typically exposed to such toxicants.

Deep-sea hydrothermal vent organisms appear to have developed enhanced defence pathways to respond to the presence of high concentrations of dissolved metals released at hydrothermal vents. Induction of antioxidant, biotransformation enzymes, or metal-binding proteins that are able to remove the reactive oxygen species formed by molecular reactions with toxic metals, or detoxification of metals by sequestering them in a non-bioavailable form 
and/or by eliminating the metal, have been observed in hydrothermal vent fauna at ecologically relevant metal concentrations at in situ temperature and hydrostatic pressure (Auguste et al., 2016; Company et al., 2006). These responses represent an energetic commitment with potential consequences for reproductive capacity and population survival (Sokolova et al., 2012). However, extrapolation from resistance in experimental exposures to resistance in the environment remains challenging: ecological processes and interactions must be understood before experiments in laboratories, micro- or meso-cosms can be related reliably to natural conditions (Mayer-Pinto et al., 2010). Further, the physical and chemical composition of the particle plume generated by mineral extraction is likely to differ significantly from the hydrothermal vent fluid and plume, as may the duration of exposure to the chemical mixtures presented by mineral extraction processes, impeding inferences regarding potential resistance to toxicological exposures among vent fauna.

The structure and functioning of benthic assemblages at vents, and to a lesser extent at seamounts, are highly dependent on key foundation species (Clark et al., 2010; Mullineaux et al., 2012) and may quickly collapse if the resistance of these species is exceeded. Large sessile suspension feeders, common at inactive vents and on seamounts, also thrive in high particle loads, although they may be sensitive to burial, distinct particle size and shapes, and toxic compounds (Boschen et al., 2016a; Fisher et al., 2014; Larsson et al., 2013). As natural sedimentation rates are extremely low on abyssal plains, the abyssal fauna are likely least tolerant to enhanced particle load and sedimentation. Although we expect that such species are to some level resistant to mining plumes, current knowledge is insufficient to predict the extent of resistance.

\subsection{Recovery after small-scale disturbance events}

\subsubsection{Hydrothermal vents}

5.2.1.1.Active vents. Active vents exhibit distinct biogeographic faunal patterns and natural background disturbance regimes, suggesting region-dependent recovery at slow- and fastspreading centres. In the last three decades, faunal recovery following volcanic eruption events were documented after the 1993 and 1998 eruptions on the intermediate-spreading Juan de Fuca Ridge (JFR) on Co-Axial Segment and Axial Volcano (Marcus et al., 2009; Tunnicliffe et al., 1997), and after the 1991 and 2006 eruptions on the fast-spreading 9oN vent field on the East Pacific Rise (EPR) (Gollner et al., 2015a; Shank et al., 1998).

At Juan de Fuca, mean mega- and macrofaunal densities reached and even exceeded pre-eruption values after 2 years (17\% mean recovery after 1 year; 290\% mean recovery after 2 years) (Fig. 4, Appendix A). Biomass showed a similar recovery response (12\% after 1 year; $102 \%$ after 2 years, Appendix A). Meio- and macrofauna abundances at the EPR also recovered relatively quickly, with no significant differences in abundances across all tubeworm sites relative to pre-eruption data (Gollner et al., 2015a). Similarly, Wilcoxon tests revealed no significant increase in mean percent recovery over years. Comparing meio- and macrofauna recovery data across Juan de Fuca and the EPR revealed that macrofauna densities recovered more quickly than meiofauna ( $p<0.01$; Fig. 5; Fig. 6). At single vent sites, such as at Tica at the EPR, recovery of abundance was slow, with mean macrofauna abundance reaching only $11-24 \%$ and mean meiofauna abundance reaching 2-9\% 1-4 years after eruption (Appendix A). However, abundance standard deviation was very high both pre- and post-eruption at this site (Gollner et al., 2015a,b, Fig. 5). For example, abundances at the Tica site varied significantly with $3125 \pm 1261$ macrofauna and $2255 \pm 3455$ meiofauna ind. per $64 \mathrm{~cm} 2$ before the eruption, and with $342 \pm 209$ macro- and $213 \pm 224$ meiofauna ind. per $64 \mathrm{~cm} 2$ four years after eruption. The natural high variability of abundances ranging several orders of magnitude, combined with low quantitative sampling (three samples per site and time), make it impossible to detect potential significant differences pre- and post-eruption. More extensive sampling is needed to understand natural variability at active vents.

Mean percent recovery of faunal diversity significantly increased from 1 to 2 years after eruption $(p=0.013)$, from 1 to 4 years $(p=0.013)$ after eruption, but not from 2 to 3 years ( $p$ $>0.05)$, 2-4 years $(p>0.05)$, or 3-4 years $(p>0.05)$ (see data Appendix A). Total mega- and 
macrofauna species richness at the Juan de Fuca vents reached $75 \%$ of the pre-disturbance values three years after the 1998 eruption (Marcus et al., 2009), and 90\% two years after the 1993 eruption (Tunnicliffe et al., 1997), representing about 30-60\% of species from the larger regional species pool. At the EPR, total mega- and macrofauna species richness reached $69 \%$ of pre- disturbance values 4.6 years after the 1991 eruption (Shank et al., 1998). After the EPR 2006 eruption, the recovery reached $55 \%$ for macrofauna and $48 \%$ for meiofauna species after 4 years (Gollner et al., 2015a) (for data see Appendix A), with $39 \%$ of the macro- and $42 \%$ of meiofaunal species returned. In addition, several new species appeared in the region, including some early colonizers that were dominant in the first post-eruption years (Gollner et al., 2015a). Species richness at Tica vent site reached $52 \%$ of pre- eruption values for macrofauna, and $106 \%$ for meiofauna after 4 years (Appendix A). At this site and time, the physical-chemical parameters of vent fluids were comparable to values measured preeruption (Gollner et al., 2015a). The fast recovery of meiofauna at Tica site shows that distinct size classes (in this case meiofauna) may recover more quickly than others. However, Wilcoxon rank tests revealed no significant differences between meio- and macrofauna diversity recovery rates, and also no differences between the EPR and JFR region (Fig. 6). The observations at Tica site in comparison to regional observations highlight that single sites may not capture regional recovery; instead several vent sites need to be studied. Similar patterns of recovery were observed using several diversity parameters (observed species richness, expected number of species, Shannon's H, Pielou's J) (Appendix A). The variability of diversity values within sites was not exceptionally high, with similar range pre- and posteruption overall (Fig. 5, Appendix A).

At the EPR and at the Juan de Fuca vents community succession patterns following major disturbance events were attributed to species responses to changes in hydrothermal vent fluid composition. Typically, vent fluid emissions were high following eruptions but declined within few years. However, biological interactions and larval dispersal and recruitment also played important roles in succession processes (Gollner et al., 2015a; Gollner et al., 2013; Mullineaux et al., 2012; Marcus et al., 2009; Shank et al., 1998; Mullineaux et al., 2003, 2009). Interestingly, post-eruption species (e.g. the limpet Ctenopelta porifera) originating from remote areas invaded disturbed and undisturbed vent sites in the region (Mullineaux et al., 2012). As a consequence, large scale mining may also indirectly influence community composition at neighboring non-mined vent sites. Meiofauna succession at the EPR was consistent with dispersal potential. Species with pelagic dispersal demonstrated rapid recovery (e.g. dirivultid copepods) (Gollner et al., 2015a), whereas species lacking pelagic dispersal stages (e.g. nematodes) demonstrated slow and poor recovery (Gollner et al., 2013). Species that were highly abundant in the region and inhabited more than one habitat pre-eruption (e.g. diverse vent- sites and the vent periphery) returned quickly after the eruption at the EPR (Gollner et al., 2015a). Populations in the vent periphery and at sites where venting recently ceased, as well as at more distant exposed basalt areas, may represent potential source population locations for vent meiofauna recovery (Gollner et al., 2015a; Gollner et al., 2013). Current observations of vent succession at 9oN on the EPR thus suggest complex recovery dynamics in meta- communities, with species differing in their ability to disperse and with successful colonizers outcompeting poor competitors.

There has not yet been a volcanic eruption documented on slow- spreading ridges, resulting in an absence of empirical data. Long- term studies at the Logatechev site (MAR) showed no major successional stages, but a decline in vesicomyid clams (probably due to a land slide) and an increase in bathymodiolin mussels, gastropods, and shrimps occurred over a 10 year period (Gebruk et al., 2010). At Lucky Strike (MAR), a 14-year study revealed stable mussel coverage (Cuvelier et al., 2011). Overall, the relatively low back- ground disturbance regimes on slow-spreading ridges suggest that recovery after natural and/or anthropogenic disturbances might be slower than at fast-spreading ridges, but this remains conjecture. As with vents on fast-spreading ridges, connectivity and colonization potential will also be essential for recovery processes at slow- spreading ridges.

Colonization potential, and therefore recovery potential after disturbance events (either natural or anthropogenic), can be described in the framework of population connectivity 
(Boschen et al., 2016b; Excoffier et al., 2013; Laurent et al., 2016; Sousa and Hey, 2013; Loewe and Allendorf, 2010; Baco et al., 2016). Genetic analyses have been performed on various vent meio-, macro-, and megafaunal species (e.g. crustaceans, bivalves, gastropods, polychaetes) in distinct geographical settings (e.g. on the MAR, the EPR, Eastern Lau Spreading Center, Kermadec back-arc basin and CIR) (Vrijenhoek, 2010; Boschen et al., 2016c). Results suggest that gene flow and migration capability between subpopulations is potentially high at both fast- and slow-spreading ridges (Breusing et al., 2015; Gollner et al., 2011; Teixeira et al., 2010; Beedessee et al., 2013). A general pattern of high intrapopulation genetic diversity and expansive population growth has emerged among various species from different vent sites (Beedessee et al., 2013; Teixeira et al., 2012; Gollner et al., 2016). However, vent organisms studied genetically are typically highly abundant and have pelagic dispersal. No study has yet analyzed patterns of genetic connectivity for vent species that are less abundant and/or lack pelagic dispersal.

Underlying mechanisms of high connectivity (migration capability) across the studied active vent species are not fully under- stood. Data on life history (i.e. reproduction, larval behaviour, juvenile settlement cues) are currently scarce. Life history traits likely play an important role, since they can allow long-term planktonic larval duration and/or rapid population growth, and connectivity between invertebrate populations is often maintained by passive larval drift. However, passive larval drift is influenced by abiotic characteristics such as plume height, or ocean currents (Hilario et al., 2015). The rate of exchange of individuals between vent fields is likely also influenced by vent field frequency and distance between individual vent sites since typically vent- restricted fauna need to migrate between isolated vent fields to ensure survival. Thus, exchange rates may be higher at closer proximity fast-spreading vent sites compared to more distantly spaced slow-spreading vent sites.

To conclude, recovery after natural volcanic eruptions at active hydrothermal vents at fast-spreading centres is highly variable but can be relatively rapid. Vent communities at fastspreading centres experience frequent volcanic eruptions (at the studied EPR location every $\sim 15$ years (Tolstoy et al., 2006)) and seem to be resilient and adapted to such natural disturbance events. Abundance and biomass values reach pre-disturbance values within a few years. However, very high variability is typically observed, pre- and post- eruption. Diversity values partly reach pre-disturbance values within only a few years, but community composition often remains different, following a sequence of faunal succession. Faunal responses differ among taxa and life history traits. The drivers of vent community resilience are diverse and include availability and composition of hydrothermal fluids as well as biotic controls such as species specific factors of dispersal and connectivity and biotic interactions of competition and predation.

However, recovery data were only available for two regions in the East-Pacific that experience frequent volcanic eruptions. Distinct biogeographic faunal patterns, distinct vent site distance and natural background disturbance regimes make it currently impossible to predict recovery rates following volcanic eruptions in other regions, and especially at slowspreading centres. Further, volcanic eruptions pave over areas which contrasts with the scraping and excavating disturbances that will be imposed by mining machines. Eruptions also do not lead to extensive sediment plumes, as are expected with mining. To what extent changes in substratum surface area and generation of (potentially toxic) sediment plumes may delay or may prevent recovery of vent communities (i.e. disruption of larval dispersal, mortality of larvae, and success of larval settlement) is currently unknown.

5.2.1.2. Inactive vents. There is currently no data available for recovery at inactive vent sites. Megafauna typically found at inactive vents includes sponges and cnidarians, such as corals (Boschen et al., 2015; Galkin, 1997; Levin et al., 2016a; Boschen et al., 2016a). Little is known about the age, growth rates, biogeography, or connectivity patterns of inactive vent megafauna. In general, such taxa are considered rather slow-growing and long-lived (hundreds to thousands years) with slow recovery rates (Clark et al., 2016). It is yet unclear whether assemblages that thrive at inactive vents are overall partly similar to active vent fauna, are similar to those inhabiting hard-substrate fauna on non-mineral rich grounds, or are unique 
(Van Dover, 2011). A recent study comparing megafaua from active and inactive chimneys off New Zealand found that deposits support unique megafauna assemblages but that species partly overlap (Boschen et al., 2016a). Similarly, a study of a young inactive vent site and active vent sites at the EPR revealed that these environments share some nematode species (Gollner et al., 2013). The finding of shared species at inactive and active vents suggests that they may provide potential source populations for each other after disturbance events (Gollner et al., 2013). Consequently, active and inactive sites in each region have to be studied to understand potential recovery after mining disturbance at active and/or inactive vents. Thus it has been suggested that both active and inactive features need to be included within a framework establishing protected areas to mitigate mining impacts at hydrothermal vents (Boschen et al., 2016b,c).

5.2.1.3.Vent periphery. Faunal recovery on basalt in the vent periphery has been studied once, following volcanic eruption disturbances on the 9oN EPR in 2006 (Gollner et al., 2015a). One year post-eruption meio- and macrofauna abundances were similar to pre-eruption abundances, but showed very high variation (Gollner et al., 2015a,b). Mean recovery of meioand macrofaua abundances were $>100 \%$ after one year (Fig. 7). Abundances varied highly with $21 \pm 28$ macrofauna and $113 \pm 147$ meiofauna ind. per $64 \mathrm{~cm} 2$ before the eruption, and with $566 \pm 685$ macro- and $1623 \pm 2599$ meiofauna ind. per $64 \mathrm{~cm} 2$ four years after eruption (Fig. 8; Appendix A). Wilcoxon rank tests revealed no significant differences between meioand macrofauna density recovery rates (Fig. 6), and there was no significant increase in percent recovery throughout the years.

Total regional macrofauna richness, primarily comprised of juvenile individuals of typical vent species, had recovered to mean $64 \%$ of pre-disturbance levels four years after a volcanic eruption (Fig. 7). Meiofauna diversity recovered more slowly than macro- fauna diversity $(p=0.021)$. Total regional meiofauna richness reached only $28 \%$ of pre-eruption values after four years (Gollner et al., 2015a). Many meiofauna species, which were rare prior to the eruption, had not returned. Thus, whilst mean richness recovery was $111 \%$ for the macrofauna, mean richness recovery was only $48 \%$ for meiofauna after four years. Rare preeruption species at individual sites were replaced by common species from the regional species pool. Other diversity measures showed compara- ble responses. Meiofauna community composition in the vent periphery changed significantly with time (e.g. dominant species one, two, and four years after disturbance were the copepod Tisbe sp. nov. 1., the copepod Amphiascus sp. 1 (aff. varians), and the ostracod Xylocythere vanharteni, respectively). Changes were similar to the ones reported for active vent meiofauna and were related to meiofauna species dispersal potential (Gollner et al., 2015a). However, Wilcoxon tests showed that mean percent diversity recovery remained similar in the vent periphery throughout the years (all $p>0.05$ ), and diversity did - in contrast to active vents - not increase with years, indicating slower recovery.

To conclude, recovery of meiofaunal vent peripheral communities is likely slower than communities at active vents. After four years, only $28 \%$ of meiofauna species of the predisturbance periphery species pool had returned to the EPR, whereas $42 \%$ of meiofauna species of the pre-disturbance vent species pool had returned to the EPR at active vents after four years. In contrast, macrofauna recovery of the pre-disturbance species pool was similar at active vents and in vent peripheral communities. Macrofauna recovery of the predisturbance vent species pool at active vents varied between $75 \%$ (Juan de Fuca, after 3 years), 69\% (EPR, after 4.6 years in 1996), and 42\% (EPR, after 4 years in 2009; not including new species), whereas macrofauna recovery of the pre- disturbance species pool in the vent periphery was $64 \%$.

The discovery of a juvenile subset of typical vent species in the vent periphery suggests the interconnection of vent periphery and active vent communities. Little is known about connectivity and dispersal rates in typical peripheral meiofauna species, but nematode species lack specific planktonic dispersal stages and demonstrate limited dispersal potential since they are rarely observed in the pelagic. In contrast, typical vent meiofauna species such as dirivultid 
copepods disperse via abundant nauplii and copepodites in the pelagic and are known for their high genetic connectivity (Gollner et al., 2015a, 2016).

The study on vent periphery recovery investigated only areas close to active sites (some meters) or recent inactive vent sites, but there is no information available on recovery potential of more distant vent peripheral communities. Also, there is no information available on recovery potential of vent peripheral communities from slow-spreading areas that are disturbed by volcanic eruptions less frequently.

\subsubsection{Seamounts}

Fisheries currently impose a severe impact on seamounts, with global catches estimated at $\sim 3$ million tonnes per year (Clark et al., 2016; Watson and Morato, 2004; Clark, 2009; Norse et al., 2012; Pitcher et al., 2010). Unfished seamounts have been observed to support double the overall benthic biomass and species richness than fished seamounts (Roberts, 2002). In particular cold-water corals and other sessile filter feeders, which provide habitat to many other benthic organisms (Baillon et al., 2012; D'Onghia et al., 2010; Pham et al., 2015), are extremely susceptible to bottom trawling (Kaiser et al., 2006; Clark and Tittensor, 2010) because they grow extremely slowly (few $\mathrm{mm}$ to $\sim 1 \mathrm{~mm}$ per year) and are long-lived (decades and centuries to millennia) (Clark et al., 2016; Roark et al., 2006; Fallon et al., 2014). Knowledge on the coral cover necessary to sustain stony coral communities (and associated species) is scarce. However, most seamounts with high trawling impact have coral cover reduced to below $30-50 \%$ of the coral cover estimated as necessary to maintain habitat viability (Clark and Tittensor, 2010).

Knowledge on recovery rates following the cessation of bottom trawling are rare, and the uniqueness of seamounts hampers a direct comparison of communities across seamounts to determine recovery rates (e.g. fished vs. unfished) because biological seamount communities experience different environmental conditions and may respond differently to physical disturbance. Thus, only seamounts with similar environmental conditions and in close vicinity can be considered eligible for comparison (Althaus et al., 2009; Williams et al., 2010; Watson and Morato, 2004).

Althaus et al. (2009) observed that mean megafauna density recovered to $33 \%$, and mean coral density to only 6\% 5-10 years after trawling ceased (Fig. 9, Appendix A). However, there were large differences in recovery among taxa, ranging from $<5 \%$ to up to $1100 \%$ for anthozoan taxa. Watson and Morato (2004) observed 23\% recovery in fish densities 15 years after fisheries collapsed and fishing ceased. Williams et al. (2010) distinguished between recovery on hard substratum (coral and rock) and on unconsolidated substratum (sand, gravel rubble). Mean megafauna density recovery was 36\% after 5 years and $111 \%$ after 10 years on hard sub- stratum, and $167 \%$ after 5 years and $143 \%$ after 10 years on unconsolidated substratum. Similar to Althaus et al. (2009), Williams et al. (2010) identified large variations among taxa (17\%-800\% after 5 years, and 13\%-2600\% after 10 years on hard substratum; $27 \%-2840 \%$ after 5 years, and $17 \%-1100 \%$ after 10 years on unconsolidated substratum; see Appendix A). Standard deviation within taxa was usually not very high (Fig. 10, Appendix A), but for many data points replicates were not available. Wilcoxon rank tests revealed no significant differences between mean mobile and sessile megafaunal density recovery (Fig. 11). Density recovery was faster on seamounts off Australia than on seamounts off New Zealand when considering only one study, but was faster on seamounts off New Zealand than on seamounts off Australia when considering two studies (Fig. 11). There was no significant increase in mean percent recovery throughout the investigated years (all $p>0.05$ ).

Althaus et al. (2009) reported mean megafauna species richness recovery of $32 \%$ after 5-10 years (Appendix A). Williams et al. (2010) presented megafauna recovery data using Simpson's diversity index that ranged from 129\% after 5 years to $198 \%$ after 10 years on hard substratum, and from $30 \%$ after 5 years to $774 \%$ after 10 years on unconsolidated substratum. Wilcoxon rank tests revealed no significant differences between mobile and sessile megafaunal diversity recovery. Mean diversity recovery was greater on seamounts off New Zealand than on seamounts off Australia (Fig. 11). However, no significant increase in mean diversity percent recovery was observed throughout the years (all $p>0.05$ ). 
To summarize, data on community recovery following bottom trawling are sparse and available only for fauna large enough to be detected using image analysis. Recovery processes in seamount megafauna show large variations depending on taxa and indicate significant changes in community composition following disturbance. A few individual taxa were found in very high abundance after trawling which may have resulted from resistance to trawling impact or from protection in natural refuges inaccessible to trawls. Alternatively, these highly abundant taxa may represent the early stage of succession after trawling impact (Williams et al., 2010). Overall, recovery to original (pre-disturbance) species richness and community composition following fisheries is likely rather slow and is predicted to take decades to centuries since many seamount taxa, especially climax species, are long-lived with slow growth and are potentially geographically isolated (Clark et al., 2016). In addition, many species live in association with thickets of a key stone coral (such as Solenosmilia variabilis) that have been built over millennia (Williams et al., 2010). Data on recovery rates of such associated meio- and macrofauna after trawling do not exist to our knowledge, but resilience may be low where fauna can only live in association with a distinct slow-growing keystone species. Our understanding of ecosystem recovery on seamounts is highly fragmentary and requires further investigation.

Impact by trawling fisheries is likely less destructive than mining. A trawl net may bounce along the seabed to some degree, so that the more flexible corals and some occasional individuals may be missed and escape damage. In the case of mining, the entire rock surface will be scraped away so the chance of avoiding removal is much slimmer. In addition, the influence of (potentially toxic) sediment plumes on larval dispersal, survival and settlement success is unknown. Faunal recovery and resilience after mining disturbance is therefore likely to be slower than recovery after trawling.

\subsubsection{Nodule fields}

Since 1970, 11 small-scale disturbance experiments have been conducted to study the potential effects of nodule mining on the benthos (reviewed by (Jones et al., 2017)). During these experiments, disturbance gear was towed over the seafloor, removing or burying nodules. These experiments were performed in three regions: the Clarion-Clipperton Fracture Zone (CCZ), Peru Basin, and Central Indian Ocean Basin (CIOB) (Jones et al., 2017).

5.2.3.1.Peru basin. During the German "DISturbance and reCOLo- nization experiment" (DISCOL), a polymetallic nodule area in the Peru Basin was artificially disturbed in 1989, using a plough harrow to simulate manganese nodule extraction. The impact by the plough created a $\sim 11 \mathrm{~km} 2$ patch-mosaic of disturbed tracks and adjacent sites disturbed indirectly by the sediment plume suspended.

DISCOL results showed that megafauna densities were still diminished 7 years after disturbance, with minimal recovery (Bluhm, 2001). Density recovery was on average only $9 \%$ for sessile megafauna, and $49 \%$ for the mobile megafauna (see Appendix A). After 26 years, megafauna densities demonstrated high variability in recovery rates among taxa, ranging from only $11 \%$ in Anthozoa to $167 \%$ in Holothuridea, and major changes in community composition persisting (unpublished data by Purser et al., Appendix A, Fig. 12, Fig. 13). In contrast, macrofauna density in sediments recovered more quickly, reaching mean recovery of $85 \%$ after 7 years (Borowski, 2001). Mean density recovery rates differed among macrofauna taxa, with several taxa reaching $\sim 100 \%$ pre- disturbance conditions (polychaetes, tanaidaceans, isopods, scaphopods, echinoids), whilst others showed lower recovery ranging from 15 to 47\% (cumaceans, bivalves, gastropods, ophiuroids) (Borowski, 2001; Borowski and Thiel, 1998) (Appendix A, Fig. 12). After 26 years, mean meiofauna densities had recovered to $90 \%$ (unpublished data by Mevenkamp, Egho \& Vanreusel, Appendix A). However, high variation in densities was observed, particularly in impacted sites. Wilcoxon tests revealed a significant increase in mean percent density recovery from 0.003 years to 0.5 years $(p=0.05)$, 3 years $(p=0.04), 7$ years $(p=0.04)$, and 26 years $(p=0.05)$. No increase was detected from 0.5 years to 3,7 and 26 years (all $p>0.05$ ), from 3 years to 7 and 26 years (all $p>0.05$ ), and from $7-26$ years $(p>0.05)$. 
Diversity was studied in less detail during DISCOL, but diversity recovery was on average only $16 \%$ for sessile megafauna, and $33 \%$ for the mobile megafauna after 7 years (Bluhm, 2001). In contrast, mean polychaete diversity had recovered to greater extent of 80-99\% (Borowski, 2001; Vopel and Thiel, 2001) (Appendix A). Diversity recovery after 26 years is currently under investigation. Wilcoxon tests showed no significant increase of mean diversity with years $(p>0.05)$.

5.2.3.2.CCZ. Total mean meiofauna, nematode, copepod and foraminifera densities recovered to pre-disturbance values within two to three years in the CCZ (Kitazato and Okamoto, 1997; Shirayama \& Fukushima,; Radziejewska, 2002) (IOM-BIE \& JET experiments). Mean macrofauna densities recovered to $93 \%$ after one year, with recovery rates ranging from $48 \%$ (amphipods) to $108 \%$ (polychaetes) (Trueblood and Ozturgut, 1997) (BIE). Mean mobile megafauna densities reached $290 \%$ of pre-disturbance values after three years (Radziejewska and Stoyanova, 2000) (IOM-BIE) (Appendix A, Fig. 12).

26 years after the OMCO disturbance experiment, mean total meiofauna densities had recovered to $105 \%$ (Appendix $A$ ), but taxa responded differently with density recovery ranging from $50 \%$ (tantulocarids) to $552 \%$ (kinorhynchs) (Mahatma, 2009) (Appendix A). Nematode abundances were significantly lower 26 years after the disturbance (Miljutin et al., 2011) with mean recovery of $73 \%$ (Appendix A). The number of meiofauna genera was higher postdisturbance (70 genera) than pre-disturbance (50 genera) (Mahatma, 2009), but nematode diversity remained significantly lower than pre-disturbance with diversity recovery only $81-94 \%$ after 26 years (Miljutin et al., 2011). Further, nematode community composition remained significantly different 26 years after disturbance (Miljutin et al., 2011). After 37 years, epifauna remained almost absent, indicating that recovery of epifauna is very slow (Vanreusel et al., 2016).

In the CCZ no clear trend of an increase of mean density percent recovery with increasing years past disturbance could be observed. Typically, percent recovery was similar among years past disturbance $(p>0.05)$, with a few exceptions (mean density recovery greater after 0.08 years $(p=0.03), 2$ years $(p<0.01), 3$ years $(p<0.01)$ and 26 years $(p=0.03)$ compared to after 0.04 years; mean density recovery greater after 3 years than compared to after 0.08 years $(p=0.03)$ and 1 year $(p=0.01))$.

5.2.3.3.Indian ocean. Almost four years after the INDEX disturbance, mean total meio- and macrofauna infauna densities had recovered to $\sim 100 \%$. Recovery differed among taxa, ranging from $27 \%$ (harpacticoids) to $290 \%$ (gastrotricha) for meiofauna taxa (Ingole et al., 2001, 2000, 2005) (Appendix A, Fig. 12). Mean percent density recovery was significantly greater 3.8 years after disturbance than 0.08 years after disturbance $(p=0.05)$.

5.2.3.4.Analyses of recovery in the Peru basin, CCZ, and Indian Ocean. Analysis of available density and diversity datasets from the Peru Basin (DISCOL), from the CCZ (JET, IOM-BIE, OMCO, BIE), and from the Indian Ocean (INDEX) reveals that absolute recovery and percent density and diversity recovery varied greatly within and among taxa (Figs. 12-14). However, there was a trend across all samples with small and mobile species recovering faster than large and sessile species (Fig. 15). Jones et al. (2017) observed the same trend. Due to lack of information owing to low taxonomic resolution in some of the original publications, we could not separate our analysis into sediment infauna and nodule epifauna. However, sessile species typically require hard substrate.

Mean density recovery was greater for mobile meiofauna than for macrofauna and megafauna. In contrast, there was no difference between mean meio- and macrofauna diversity recovery (Fig. 15). However, both meiofauna and macrofauna diversity recovered more quickly than megafauna diversity (Fig. 15).

Mobile megafauna diversity showed greater recovery than sessile megafauna diversity (Figs. 13 and 15). The response of megafauna may reflect differences in feeding guilds: mobile species are typically detritus feeders or scavengers (such as ophiuroids, holothurians, polychaetes) whereas sessile species are typically filter-feeding (such as poriferans, 
anthozoans, cnidarians). Mobile and sessile macrofauna taxa showed similar percent recovery in density (diversity data were not available). Some mobile taxa such as peracarids that are assumed to have limited capacity for dispersal due to brooding reproductive mode, show recovery similar to sessile macrofaunal taxa, suggesting a role for reproductive strategy in recovery potential. Thus low population connectivity in deep-sea species such as polychaetes or isopods (Janssen et al., 2015) implies slow recovery potential after disturbance.

To summarize, disturbance experiments designed to mimic polymetallic nodule mining on abyssal plains have provided first insight into recovery processes after small-scale disturbance events on abyssal plains with nodules. Analysis of faunal densities indicates that mobile and smaller organisms tend to have greater recovery potential, sometimes reaching or exceeding pre- disturbance levels following disturbance. However, in some cases meiofauna density had not recovered even 26 years after disturbance (Miljutin et al., 2011). Fewer diversity data were available, and the taxonomic resolution of analyses varied considerably among studies from species to order level. Further, different diversity parameters were used (e.g. number of taxa, Shannon's H, Pielou's J) in different studies. Nonetheless, diversity recovery appears greater for mobile and small organisms, although there were exceptions (e.g. nematode diversity had not recovered after 26 years (Miljutin et al., 2011)). In all cases, there was high variance in recovery rates among taxa, preventing prediction of a general pattern of recovery or a sequence of successional stages at nodule fields. Despite this, it is clear that large sessile fauna have very slow recovery after disturbance.

Changes in species abundances following small-scale test mining may be linked to multiple factors. Some taxa have exceeded pre-disturbance density values, and may represent opportunistic species (Norkko et al., 2006). Others showed slow or no recovery. Understanding connectivity may be a key parameter for predicting recovery after large-scale disturbances (Janssen et al., 2015). Further, substratum availability is essential for the nodule epifauna. Without hard-substratum (nodules), nodule epifauna are unlikely to recover. The response of some fauna may be further linked to biotic controls. Increases in faunal densities after disturbance at DISCOL and in the CCZ may be related to enhanced food (phyto-detritus) inputs (Bluhm, 2001; Borowski, 2001; Borowski and Thiel, 1998; Radziejewska, 2002; Radziejewska and Stoyanova, 2000; Ahnert and Schriever, 2001). There is a clear need to assess natural community variance over time and spatial scale in order to be able to understand impacts of disturbance.

The scale of disturbance experiments was rather small in all cases (a few km2) in comparison to the disturbance scale anticipated for nodule mining activities (>100 km2). Our analyses revealed for example that mean megafauna densities recovered quicker after a smaller-scale disturbance in the CCZ (single test mining track) than after a larger scale disturbance (several $\mathrm{km} 2$ ) at DISCOL. The underlying reasons for this observation may be diverse (different taxa and regions were observed), but scale of disturbance

may have influenced recovery. Mining of large areas could disrupt faunal connectivity and thus prolong or impede recovery. In addition, the effect of (potentially toxic) sediment plumes on e.g. larval dispersal and recruitment is unknown. Faunal resilience to and recovery from mining-disturbance is likely to be (much) slower than recovery after small-scale disturbance experiments.

\subsection{Reversibility after mineral mining impacts}

In the context of the United Nations Convention on the Law of the Sea (UNCLOS), the International Seabed Authority (ISA) must ensure effective protection of the marine environment on behalf of humankind. In the international legal context this includes that "serious harm" must be avoided during deep-sea mining. However, the definition of "serious harm" is challenging in deep ecosystems, where lack of knowledge is the rule rather than the exception (Levin et al., 2016b). Mineral mining will modify or remove substrata that organisms inhabit, and sediment plumes will affect areas beyond mining sites. A key question is whether similar species or functional groups will recover in modified environments, or if disturbed areas will shift to altered or depauperate states. Whether processes are reversible and whether the 
deep-sea system can re- turn to pre-disturbance condition requires investigation (Palumbi et al., 2008; Lotze et al., 2011).

To date, large-scale commercial mineral mining has not taken place. Nonetheless, we need to understand and predict resilience of communities to these disturbances in order to be able to define "serious harm" and to propose successful mitigation actions. To estimate reversibility, it has to be considered that the nature and scale of mining disturbance will be different to the above described recovery scenarios. Volcanic eruptions pave over areas of seabed in a single locality. A trawl net may bounce a little along the seabed so that not all fauna are entirely removed. Experiments that mimic nodule mining typically did not remove nodules but buried them, and the disturbed area was considerably smaller than expected for future mining scenarios. The spatial (at most a few $\mathrm{km} 2$ ) and temporal (typically independent events) scales of disturbances were in significantly more limited than those proposed for any mining activities, which may range from 100's to 1000's km2 per nodule mining operation per year (Wedding et al., 2015), from 10's to 100's km2 for crust mining (Hein et al., 2009), and some hectares per polymetallic sulphide mining operation (Van Dover et al., 2014). The scale of mining operations will result in habitat fragmentation which may affect reversibility. Large continuous nodule fields will be fragmented into a system of smaller-sized nodule fields. Naturally patchily distributed active and inactive hydrothermal vents and seamounts will be further fragmented by large-scale mining.

Direct mining impacts will include mortality and removal of fauna living on mined substrata in all targeted ecosystems. Removal of nodules will cause habitat loss for hard substrata fauna on a geological time scale because nodules reform at rates of $\mathrm{mm}$ per million year. At hydrothermal vents and seamounts mineral rich rocks will be removed, leaving mineral-poor rocks which prevents thriving of species exclusively relying on mineral rich crusts. At nodule fields, fauna living in the sediments may be killed by sediment compression. Sediments below and adjacent to nodules will be compacted by vehicle tracks, which may result in long-term changes in sediment porewater geochemistry (Petersen et al., 2016). Potentially toxic sediment plumes may affect areas beyond the directly mined locality (SPC, 2013; SPC, 2013; SPC, 2013). To estimate the reversibility of mineral mining impacts, geological timescale of habitat/mineral reformation as well as biological timescale and mode of community recovery need to be considered.

\subsubsection{Hydrothermal vents and polymetallic sulphides}

5.3.1.1. Active vents. Reversibility of mineral mining impacts at active vents will depend on the frequency and scale of sulphide mining operations. Assuming that vent fluids do not change dramatically and that connectivity of species in not disrupted, recovery of active vent communities at fast-spreading centres may occur within decades. However, large-scale mining may substantially diminish species populations and could hinder recolonization by disrupting connectivity of source populations (Van Dover, 2014; Boschen et al., 2016a). The loss of foundation species may hinder the settlement of associated fauna, and may indicate a tipping point where resilience capacity is exceeded and the system transitions to a new state. Alternative states at active vents may be dominated by bacterial mats instead of rich faunal communities.

The loss of topographic features such as black smokers may change settlement behaviour, and thus diversity of fauna (Mullineaux and Butman, 1990). Typically, active black smokers can reform within several months or years at fast-spreading centres (Nautilus Minerals, 2008), but consequences of large scale mining on local fluid composition are not know. Sulphide mining at hydrothermal vents may cause local modification of vent fluid regimes (i.e. flow rates, distribution, chemistry) by clogging vent fluid channels (Van Dover, 2014), with severe consequences for active vent communities which depend on fluid regimes. Low-diversity communities are typically associated with high temperature venting (i.e. around black smokers), whereas higher diversity is linked to low-temperature venting (Gollner et al., 2015b; Fisher et al., 2007). Further, symbiotic foundation species such as tubeworms, snails, or mussels only thrive in specific vent regimes (Fisher et al., 2007). Therefore, modification of vent-fluid regimes could cause local habitat loss or change community composition at active 
hydrothermal vents, as well as at sites that are not directly affected by mining (Nakajima et al., 2015).

Set-aside areas are suggested as part of environmental management strategies to mitigate mining effects. Such areas should preserve biodiversity that may be lost at a mine site and should support connectivity among populations of vent organisms within the region. Setaside areas must be suitably connected by the transport of larvae to ensure exchange of genetic material among remaining populations (Boschen et al., 2016b). Ideally, set-aside areas provide source populations for the recovery of the mined site (Boschen et al., 2016b).

5.3.1.2. Inactive vents and vent periphery. The scarce knowledge on species diversity, role of functional groups, species distribution, connectivity, and settlement behaviour makes it impossible to estimate reversibility potential at inactive vents and in vent peripheral areas following mining disturbances. Primary considerations include permanent modification of topography, and change of mineral composition. Removal of polymetallic sulphide substratum at inactive vents cannot be reversed due to lack of active hydro- thermal fluids (Boschen et al., 2013). Habitat homogeneity (smoothing), or habitat heterogeneity (roughening) may increase during collection of mineral resources (Boschen et al., 2013; Fukushima and Okamatsu, 2010). Substratum will be altered from mineral-rich to mineral-poor rock at inactive vent sites. Yet it is not known to what extent, if at all, species will be able to settle and grow in such modified environments. That inactive vents and vent periphery areas harbour unique communities but also share several species with active vent areas (Boschen et al., 2016a; Gollner et al., 2013; Sen et al., 2016) highlights the importance of including hydrothermally active and inactive areas within networks of protected areas (Boschen et al., 2016a).

\subsubsection{Seamounts}

Habitat structure on seamounts will be changed by removal of upper centimeters of crust, and functional groups such as 100- or 1000-year old corals and their associated fauna will be removed, potentially resulting in slow (century-scale) recovery (Clark et al., 2016). Loss of crusts may hinder colonization of substratum specific seamount species or prohibit recovery (Boschen et al., 2015; Mullineaux and Butman, 1990; Schlacher et al., 2013). Changes in topographic features may affect settlement behaviour (Mullineaux and Butman, 1990) and thus diversity of fauna in the long term. Cumulative effects may be especially severe around seamounts. Many seamounts are subject to fisheries impacts, and shifting ocean temperatures, oxygenation, and acidification may adversely affect distant source populations and thus may hinder recovery (Ramirez-Llodra et al., 2011).

In addition, seamount faunas vary even at local $(\mathrm{km})$ spatial scales (O'Hara and Tittensor, 2010; Schlacher et al., 2014; Clark et al., 2012). Variation in community composition and diversity has been related to depth and seabed structure (e.g. relief, substrate type, presence of bio-constructors), as well as current regimes and distance to source populations, amongst others factors (Boschen et al., 2015; Clark et al., 2010; Schlacher et al., 2014). Connectivity among seamount populations reveals contrasting patterns among species. Some seamount species are distributed across large geographic distances (e.g. some corals (Clark et al., 2010; Miller et al., 2010; Smith et al., 2004); fish (Smith et al., 2002); harpacticoid copepods (Packmor et al., 2015)), whereas other coral and fish species have much more restricted distributions (Baco and Shank, 2005; Smolenski et al., 1993; Stockley et al., 2005). Several studies highlight high uniqueness in seamount fauna (Richer de Forges et al., 2000), but these may simply reflect low sampling effort (Clark et al., 2010). There is evidence that connectivity is directly linked to life history patterns (Samadi et al., 2006); many seamount fauna appear to have non-planktotrophic larvae implying restricted dispersal potential (Clark et al., 2010; Althaus et al., 2009; Parker and Tunnicliffe, 1994). However, there is contrasting evidence that wide geographic distributions exist in putatively poor dispersers (Packmor et al., 2015; Shank, 2010). McClain et al. (2009) revealed that more than $70 \%$ of species in the megafaunal assemblages on a North Pacific seamount were cosmopolitan. The inconsistency of these results may reflect the complex interplay of several ecological and evolutionary 
processes shaping seamount systems, or may be linked to the paucity of genetic studies on seamount species (Shank, 2010).

Biogeography and connectivity of fauna, as well as abiotic characteristics that influence seamount fauna composition need to be understood and considered in any mining mitigation concept. Recovery will be slow at seamounts and modifications made by mining may be too great to allow for return to pre-disturbance community composition and abundance. Spatial management employing a systematic method to identify Ecologically or Biologically Significant Areas (EBSA criteria) for protection may help to mitigate mining effects (Clark et al., 2014).

\subsubsection{Nodule fields}

Removal of nodules will be associated with local loss of nodule-specific fauna. Fauna relying on nodules as a hard substratum may remain absent until the substratum recovers, i.e. for millions of years. Species ranges and source/sink dynamics of the nodule- inhabiting fauna are unknown and it is unclear whether populations can survive in unaffected refugia. Any refugia should harbour similar nodule density as mined sites, since epifaunal densities and nodule coverage are linked. Nodule dense areas harbour more than two times higher epifaunal densities, and corals are essentially absent in nodule-free areas (Vanreusel et al., 2016). It is currently unknown whether species are endemic to nodules or whether adjacent seamount crusts host partly the same species as nodules. Future studies should explore whether adjacent sea- mounts host potential source populations capable of recolonising impacted habitats (Singh et al., 2016) or capable of maintaining connectivity among undisturbed areas. The potential responses of communities to mitigation and restoration actions, such as deployment of artifical nodules, are currently unknown.

Sediment-dwelling fauna in mined nodule areas may also experience density decreases below a critical threshold. Sediments will be compacted by vehicle tracks, which may result in changes in sediment porewater geochemistry. The organic-rich upper sediment layer, which is a food source for most sediment feeders, will be removed by the collector and/or re-suspended. The sediment that redeposits from the plume in the immediate vicinity of the collector may have an average composition of the topmost $10-25 \mathrm{~cm}$ of the sediment and thus will have an altered chemical composition relative to the pre-disturbance sediment (Petersen et al., 2016). Some long-term disturbance experiments reported that sediment-dwelling fauna had not recovered after almost 30 years, potentially because organisms were unable to penetrate compacted sediments (Miljutin et al., 2011). However, other studies demonstrated density recovery potential for some sediment fauna. Nonetheless, nodules grow in areas with low sedimentation rates (<20 $\mathrm{mm}$ per thousand years) (Petersen et al., 2016) and it will therefore take at least several decades to millennia for sediment layers to recover. Despite this, it remains difficult to estimate whether sediment compaction and/or extraction of upper sediment layers will affect density and or diversity of sediment infauna over an extended timescale (decades to centuries), or whether recovery to the pre-disturbance state is possible.

\subsubsection{Areas adjacent to mining sites}

Enhanced sedimentation caused by mining-generated sediment plumes in areas surrounding mining sites may harm suspension and deposit feeders, causing depletion of functional groups and shifts in community composition (Fukushima et al., 2000). On abyssal plains, sedimentation will modify grain size composition, which can change community composition (Blake et al., 2009). Potentially toxic plumes will impose additional stress on organisms and may eventually become lethal (Sokolova et al., 2012). Decreasing effective population size, loss of subpopulations, and/or loss of populations in mined areas may hinder population exchange and diminish genetic diversity in areas surrounding mining sites (Boschen et al., 2016b). Fauna may be able to resist these stressors partly or may be able to recover from stressors. However, it is not yet possible to estimate the effect of these cumulative effects, or predict whether they will result in irreversibility of changes, causing altered ecosystem states in areas surrounding mining. 


\section{Conclusion}

Resilience e the ability of a system to maintain structure and function, in the face of internal change and external disturbances e is a complex interplay of different processes, including the resistance of species and communities to alterations, their recovery potential following disturbance events, and the potential reversibility of ecosystem changes.

The capacity for populations of deep-sea species to stay essentially unchanged despite stress and disturbances (resistance sensu (Grimm and Wissel, 1997)) associated with deepsea mining remains uncertain. Our review on resistance revealed that species may be to some level resistant to (potentially toxic) mining plumes or electromagnetic radiation, but current knowledge is insufficient to predict the extent of resistance.

We performed meta-analyses on post-disturbance population density and diversity mean percent recovery, after disturbances most similar to mining: volcanic eruptions at vents, fisheries on seamounts, and experiments designed to mimic nodule mining on abyssal plains. Communities can recover to some extent after mining-related disturbance events since mean percent recovery density and diversity values are above cero (Fig. 16). Mean recovery was highly variable in distinct ecosystems and among benthic taxa and variability among samples was often very high. In addition, as stated by Jones et al. (2017), many past recovery studies have limitations that reduce their effectiveness in determining responses. Our results can show some potential large scale trends, but current knowledge is far from showing the complete picture.

At active vents, an increase in diversity percent recovery was observed with increasing time past disturbance. Communities at active hydrothermal vents at frequently naturallydisturbed fast- spreading ridges can recover after such punctual natural disturbance events and follow a sequence of succession, related to abiotic (e.g. hydrothermal fluid regime) and biotic (e.g. larval dispersal, predation, competition) factors. We lack data on recovery potential from communities along slow-spreading ridges with long volcanic eruption intervals, but suggest that fauna at those communities may recover (much) more slowly.

Knowledge on recovery from communities at inactive vents is lacking. In the vent periphery no significant increase of diversity with increasing time past disturbance was detected. In general, recovery is expected to be slower compared to active vents since climax species typically have longer life times (decades to centuries) and a higher proportion of rare species is present at inactive vents and in the vent periphery.

Recovery of keystone species from seamounts is typically slow. Some species, that may have survived seamount fisheries trawling or that present the early stages of succession after disturbance were highly abundant after 5-10 years but other pre-disturbance keystone species such as century old stony corals showed very little sign of recovery. Meta-analyses revealed no significant increase of mean percent density or diversity recovery with increasing time past disturbance, pointing to overall slow recovery processes.

Similarly, sessile megafauna associated with nodules showed very slow recovery after disturbance, whilst small and mobile taxa recovered or exceeded pre-disturbance densities after a few years. Meta-analyses of mean percent recovery revealed that small animals typically recover faster than large animals, and that mobile animals typically recover faster than sessile species. These results are in accordance with Jones et al. (2017). Larger spatial scale impacts at DISCOL may have prolonged faunal recovery in comparison to smaller spatial scale impacts in the CCZ.

There are no data available on reversibility after mining impacts, because large-scale mining has not yet been carried out. Nodule- mining is expected to have large-scale and longterm impacts, particularly on the resident nodule-encrusting and crevice fauna, and abyssal plains may shift to altered or depauperate states through removal of and change in substrata. Similarly, local modification of fluid sources at active vents may result in loss or change of chemosynthetic communities in exploited areas. Local extinction of keystone species, or loss of mineral-specific faunas, may cause long-term or even permanent shifts in community composition at vents and seamounts. 
There are significant knowledge gaps with implications for understanding faunal recovery and resilience patterns following mining impacts (Table 1). Lack of knowledge concerns scales of mining operations, faunal recovery processes after large-scale disturbances, spatial and temporal influences on faunal community composition. Cumulative impacts may lead to unexpected ecosystem changes and need to be investigated (Van Dover, 2014). Cumulative impacts refer to the interaction of several mining operations within a given area, but also to additional non-mining related natural and human impacts such as volcanic eruptions (vents), fishing (seamounts), and changes in physical and geochemical ocean parameters (e.g. temperature, $\mathrm{pH}, \mathrm{O} 2$ ). In addition, potential community responses to mitigation and restoration actions are currently unknown. Substantial community shifts, including the loss of species, may persist over geological timescales at directly mined sites due to habitat loss (mineral removal). Therefore, spatial environmental management to detect and establish set-asides, protected areas of similar seafloor habitat as to be mined areas, may be especially important to mitigate species loss and maintain regional biodiversity (Swaddling, 2016). Future research needs to substantially increase baseline knowledge: effective environmental management of deep-sea mining is dependent on data identifying the extent of resistance to and capacity to recover from extractive activities in deep-sea benthic communities.

Contributions: Gollner, Kaiser, Menzel, Brown, and Mestre reviewed the literature and wrote the manuscript; Gollner, Kaiser, Menzel, and Jones collected data for meta-analyses; Menzel carried out $\mathrm{R}$ analyses; all authors critically commented on this review. The review was initiated by members of the MIDAS project (Managing Impacts of Deep-seA reSource exploitation, a European framework program), and is an outcome of WP6 (ecosystem resilience and recovery, WP leader: Martinez Arbizu). All authors have approved the final article.

Declaration of interest: There is no conflict of interest.

\section{Acknowledgments}

The research leading to these results has received funding from the European Union Seventh Framework Programme (FP7/2007- 2013) under the MIDAS project, grant agreement no 603418. We thank S. Frickenhaus for helping to write the R script. AC is supported by Program Investigador (IF/00029/2014/CP1230/CT0002) from FCT. DC is supported the post-doctoral scholarship (SFRH/ BPD/110278/2015) from FCT. MC and AS-V acknowledge the Spanish RTD project NUREIEV (ref. CTM2013-44598-R) funded by the Ministry of Economy and Competitiveness, and grant 2014 SGR 1068 to CRG Marine Geosciences funded by Generalitat de Cata- lunya autonomous government. The research leading to these results also received funding from the European Union Horizon 2020 research and innovation programme under grant agreement 689518 (MERCES). This study also had the support of Fundaçao para a Ciencia e a Tecnologia, through the strategic project UID/MAR/ 04292/2013 granted to MARE. The SO239 \& SO242 cruises and accompanying work was funded by the German Ministry of Research (BMBF, grant no. 03F0707A-G) through the project Mining Impact of the Joint Programming Initiative Healthy and Productive Seas and Oceans. We thank two anonymous reviewers for their very constructive comments and suggestions. TM is supported by the Program Investigador FCT (IF/01194/2013/CP1199/CT0002).

Appendix A. Supplementary data

Supplementary data related to this article can be found at http:// dx.doi.org/10.1016/j.marenvres.2017.04.010. 


\section{References}

Aguilar de Soto, N., Kight, C., 2016. Physiological effects of noise on aqautic animals. In: Solan, M., Whiteley, N.M. (Eds.), Stressors in the Marine Environment. Oxford University Press, Oxford, pp. 135-158.

Ahnert, A., Schriever, G., 2001. Response of abyssal Copepoda Harpacticoida (Crustacea) and other meiobenthos to an artificial disturbance and its bearing on future mining for polymetallic nodules. Deep-Sea Res. Part II 48, 17-18.

Althaus, F., Williams, A., Schlacher, T.A., Kloser, R.J., Green, M.A., Barker, B.A., Bax, N.J., Brodie, P., Schlacher-Hoenlinger, M.A., Althaus, F., Williams, A., Schlacher, T.A., Kloser, R.J., Green, M.A., Barker, B.A., Bax, N.J., Brodie, P., Schlacher-Hoenlinger, M.A., 2009. Impacts of bottom trawling on deep-coral ecosystems of seamounts are long-lasting. Mar. Ecol. Prog. Ser. 2009 (397), 279-294.

Atkins, M.S., Teske, A.P., Anderson, O.R., 2000. A survey of flagellate diversity at four deepsea hydrothermal vents in the eastern pacific ocean using structural and molecular approaches. J. Eukaryot. Microbiol. 47 (4), 400-411.

Auguste, M., Mestre, N.C., Rocha, T.L., Cardoso, C., Cueff-Gauchard, V., Le Bloa, S., Cambon-Bonavita, M.A., Shillito, B., Zbinden, M., Ravaux, J., Bebianno, M.J., 2016. Development of an ecotoxicological protocol for the deep-sea fauna using the hydrothermal vent shrimp Rimicaris exoculata. Aquat. Toxicol. 175, 277-285.

Baco, A.R., Shank, T.M., 2005. Population genetic structure of the Hawaiian precious coral Corallium lauuense (Octocorallia: Coralliidae) using microsatellites. In: Freiwald, A., Roberts, J.M. (Eds.), ColdwaterCorals and Ecosystems. Springer- Verlag, Berlin, Heidelberg, pp. 663-678.

Baco, A.R., Etter, R.J., Ribeiro, P.A., von der Heyden, S., Beerli, P., Kinlan, B.P., 2016. A synthesis of genetic connectivity in deep-sea fauna and implications for marine reserve design. Mol. Ecol. 25 (14), 3276-3298.

Baillon, S., Hamel, J.-F., Wareham, V.E., Mercier, A., 2012. Deep cold-water corals as nurseries for fish larvae. Front. Ecol. Environ. 10 (7), 351-356.

Bates, A.E., Lee, R.W., Tunnicliffe, V., Lamare, M.D., 2010. Deep-sea hydrothermal vent animals seek cool fluids in a highly variable thermal environment. Nat. Commun. 1 (14).

Beedessee, G., Watanabe, H., Ogura, T., Nemoto, S., Yahagi, T., Nakagawa, S., Nakamura, K., Takai, K., Koonjul, M., Marie, D.E.P., 2013. High connectivity of animal populations in deep-sea hydrothermal vent fields in the central Indian Ridge relevant to its geological setting. PLoS One 8 (12), e81570.

Benjamini, Y., Hochberg, Y., 1995. Controlling the false discovery rate: a practical and powerful approach to multiple testing. J. R. Stat. Soc. Ser. B 57, 289-300.

Blake, J.A., Maciolek, N.J., Ota, A.Y., Williams, I.P., 2009. Long-term benthic infaunal monitoring at a deep-ocean dredged material disposal site off Northern Cali- fornia. Deep-Sea Res. II 56, 1775-1803.

Bluhm, H., 2001. Re-establishment of an abyssal megabenthic community after experimental physical disturbance of the seafloor. Deep-Sea Res. II 48, 3841-3868.

Borowski, C., 2001. Physically disturbed deep-sea macrofauna in the Peru Basin, southeast Pacific, revisited 7 years after the experimental impact. Deep-Sea Res. II 48, 38093839.

Borowski, C., Thiel, H., 1998. Deep-sea macrofaunal impacts of a large-scale physical disturbance experiment in the Southeast Pacific. Deep-Sea Res. Part II Top. Stud. Oceanogr. 45, 55-81.

Boschen, R.E., Rowden, A.A., Clark, M.R., Pallentin, A., Gardner, J.P.A, 2016a. Seafloor massive sulfide deposits support unique megafaunal assemblages: implications for seabed mining and conservation. Mar. Environ. Res. 115, 78-88. 
Boschen, R.E., Rowden, A.A., Clark, M.R., Gardner, J.P.A., 2013. Mining of deep-sea seafloor massive sulfides: a review of the deposits, their benthic communities, impacts from mining, regulatory frameworks and managment strategies. Ocean Coast. Manag. 84, 54-67.

Boschen, R.E., Rowden, A.A., Clark, M.R., Barton, S.J., Pallentin, A., Gardner, J.P.A., 2015. Megabenthic assemblage structure on three New Zealand seamounts: implications for seafloor massive sulfide mining. Mar. Ecol. Prog. Ser. 523, 1-14.

Boschen, R.E., Collins, P.C., Tunnicliffe, V., Carlsson, J., Gardner, J.P.A., Lowe, J., McCrone, A., Metaxas, A., Sinniger, F., Swaddling, A., 2016b. A primer for use of genetic tools in selecting and testing the suitability of set-aside sites protected from deep-sea seafloor massive sulfide mining activities. Ocean Coast. Manag.122, 37-48.

Boschen, R.E., Rowden, A.A., Clark, M.R., Gardner, J.P.A., 2016c. Limitations in the use of archived vent mussel samples to assess genetic connectivity among Seafloor Massive Sulfide deposits: a case study with implications for environmental management. Front. Mar. Sci. 2 (105) http://dx.doi.org/10.3389/ fmars.2015.00105, 2(105).

Breuer, E., Stevenson, A.G., Howe, J.A., Carroll, J., Shimmield, G.B., 2004. Drill cutting accumulations in the Northern and Central North Sea: a review of environ- mental interactions and chemical fate. Mar. Pollut. Bull. 48, 12-25.

Breusing, C., Johnson, S.B., Tunnicliffe, V., Vrijenhoek, R.C., 2015. Populations structure and connectivity in Indo-Pacific deep-sea mussels of the Bathymodiolus septemdierum complex. Conserv. Genet. 16, 1415-1430.

Burritt, D.J., Lamare, M.D., 2016. The cellular respones of marine algae and invertebrates to ultraviolet radiation, alone and in combination with other common abiotic stressors. In: Solan, M., Whiteley, N.M. (Eds.), Stressors in the Marine Environment. Oxford University Press, Oxford, pp. 117-134.

Chamberlain, S., Vision in hydrothermal vent shrimp Philosophical Transactions of the Royal Society B: Biological Sciences, 355(1401), 1151-1154 DOI: 10.1098/ rstb.2000.0657. Philosophical Transactions of the Royal Society B: Biological Sciences, 2000. 355(1401): p. 1151-1154.

Childress, J.J., Fisher, C.R., 1992. The biology of hydrothermal vent animals: physiology, biochemistry and autotrophic symbiosis. Oceanogr. Mar. Biol. Annu. Rev. 30, 337-441.

Clark, M.R., 2009. Deep-sea seamount fisheries: a review of global status and future prospects. Lat. Am. J. Aquatic Res. 37 (3), 501-512.

Clark, M.R., Smith, S., 2013. Environmental Management Considerations. In: Deep Sea Minerals: Manganese Nodules, A Physical, Biological, Environmental and Technical Review, SPC1B, pp. 27-41.

Clark, M.R., Tittensor, D.P., 2010. An index to assess the risk to stony corals from bottom trawling on seamounts. Mar. Ecol. 31, 200-211.

Clark, M.R., Rowden, A.A., Schlacher, T., Williams, A., Consalvey, M., Stocks, K.I., Rogers, A.D., O'Hara, T.D., White, M., Shank, T.M., Hall-Spencer, J.M., 2010. The ecology of seamounts: structure, function, and human impacts. Annu. Rev. Mar. Sci. 2, 253-278.

Clark, M., Kelley, C., Baco, A., Rowden, A., 2011. Fauna of Cobalt-rich Ferromanganese Crust Seamounts. Technical Study No. 8, ISA.

Clark, M.R., Schlacher, T.A., Rowden, A.A., Stocks, K.I., Consalvey, M., 2012. Science priorities for seamounts: research links to conservation and management. PLoS One 7, e29232.

Clark, M.R., Rowden, A.A., Schlacher, T.A., Guinotte, J., Dunstan, P.K., Williams, A., O'Hara, T.D., Watling, L., Niklitschek, E., Tsuchida, S., 2014. Identifying ecologically or biologically significant areas (EBSA): a systematic method and its application to seamounts in the South Pacific Ocean. Ocean Coast. Manag. 91, 65-79.

Clark, M.R., Althaus, F., Schlacher, T., Williams, A., Bowden, D., Rowden, A.A., 2016. The impacts of deep-sea fisheries on benthic communities: a review. ICES J. Mar. Sci. 73, 51-69. 
Coffey Systems, 2008. Environmental Impact Statement Generated for Nautilus Solwara 1 Project, p. 50.

Colaço, A., Desbruye'res, D., Comtet, T., Allayse, A.-M., 1998. Ecology of the Menez

Gwen hydrothermal field (Mid-Atlantic Ridge/Azores Triple Junction). Cah. Biol. Mar. 39 (3-4), 237-240.

Collins, P.C., Kennedy, R., Van Dover, C.L., 2012. A biological survey method applied to seafloor massive sulphides (SMS) with contagiously distributed hydrothermal-vent fauna. Mar. Ecol. Prog. Ser. 452, 89-107.

Company, R., Serafim, A., Cosson, R., Camus, L., Shillito, B., Fiala-Medioni, A., Bebianno, M.J., 2006. The effect of cadmium on antioxidant responses and the susceptibility to oxidative stress in the hydrothermal vent mussel Bathy- modiolus azoricus. Mar. Biol. 148, 817-825.

Copley, J.T.P., Flint, H.C., Ferrero, T.J., Van Dover, C.L., 2007a. Diversity of meiofauna and free-living nematodes in hydrothermal vent mussel beds on the northern and southern East Pacific Rise. J. Mar. Biol. Assoc. U. K. 87 (5), 1141-1152.

Copley, J.T.P., Jorgensen, P.B.K., Sohn, R.A., 2007b. Assessment of decadal-scale ecological change at a deep Mid-Atlantic hydrothermal vent and reproductive timeseries in the shrimp Rimicaris exoculata. J. Mar. Biol. Assoc. U. K. 87, 859-867.

Cordes, E.E., Jones, D.O., Schlacher, T.A., Amon, D.J., Bernardino, A.F., Brooke, S.,

Carney, R., DeLeo, D.M., Dunlop, K.M., Escobar-Briones, E.G., Gates, A.R.,

Ge'nio, L., Gobin, J., Henry, L.-A., Herrera, S., Hoyt, S., Joye, S., Kark, S.,

Mestre, N.C., Metaxas, A., Pfeifer, S., Sink, K., Sweetman, A.K., Witte, U.F., 2016. Environmental impacts of the deep-water oil and gas industry: a reivew to guide management strategies. Front. Environ. Sci. 4, 58.

Correa, C.A., Mendoza, M.E., Etter, A., Pe'rez Salicrup, D.R., 2016. Habitat connectivity

in biodiversity conservation: a review of recent studies and applications. Prog. Phys. Geogr. 40 (1), 7-37.

Costa, K.M., McManus, J.F., Boulahanis, B., Carbotte, S.M., Winckler, G., Huybers, P.J., Langmuir, C.H., 2016. Sedimentation, stratigraphy and physical properties of sediment on the Juan de Fuca Ridge. Mar. Geol. 380, 163-173.

Cumming, G.S., Olsson, P., Chapin, F.S., Holling, C.S., 2012. Resilience, experimen- tation, and scale mismatches in social-ecological landscapes. Landsc. Ecol. http://dx.doi.org/10.1007/s10980-012-9725-4.

Cuvelier, D., Sarrazin, J., Colaço, A., Copley, J., Glover, A., Tyler, P., Serrao Santos, R.,

Desbruyeres, D., 2011. Community dynamics over 14 years at the Eiffel tower hydrothermal edifice on the Mid-Atlantic Ridge. Limnol. Oceanogr. 56, 1624-1640.

Cuvelier, D., Beesau, J., Ivanenko, V.N., Zeppilli, D., Sarradin, P.-M., Sarrazin, J., 2014. First insights into macro-and meiofaunal colonisation patterns on paired wood/ slate substrata at Atlantic deep-sea hydrothermal vents. Deep-Sea Res. I 87, 70-81.

Dugolinsky, B.K., Margolis, S.V., Dudley, W.C., 1977. Biogenic influence on growth of manganese nodules. J. Sediment. Petrol 47, 428-445.

D'Onghia, G., Maiorano, P., Sion, L., Giove, A., Capezzuto, F., Carlucci, R., Tursi, A., 2010. Effects of deep-water coral banks on the abundance and size structure of the megafauna in the Mediterranean Sea. Deep-Sea Res. Part II 57, 397-411.

Excoffier, L., Dupanloup, I., Huerta-Sanchez, E., Sousa, V.C., Foll, M., 2013. Robust demographic inference from genomic and SNP data. PLoS Genet. 9, e1003905. Fallon, S.J., Threser, R.E., Adkins, J., 2014. Age and growth of the cold-water scleractinian Solenosmilia variabilis and its reef on SW Pacific seamounts. Coral Reefs 33, 31-38.

Fisher, C.R., Takai, K., Le Bris, N., 2007. Hydrothermal vent ecosystems. Oceanography 20 (1), 14-23.

Fisher, C.R., Hsing, P.-Y., Kaiser, C.L., Yoerger, D.R., Roberts, H.H., et al., Footprint of deepwater Horizon blowout impact to deep-water coral communities. Proceedings of the National academy of sciences 2014. 111: p. 11744-11749. 
Fukushima, T., Okamatsu, A., 2010. Current issues in seafloor massive sulfide mining development. In: ISOPE (Ed.), The Twentieth International Offshore and Polar Engineering Conference.

Fukushima, T., Shirayama, Y., Kuboki, E., 2000. The characteristics of deep-sea epifaunal megabenthos community two years after an artificial rapid deposition event. Publ. Seto Mar. Biol. Lab. 39 (1), 17-27.

Galkin, S.V., 1997. Megafauna associated with hydrothermal vents in the manus Back-Arc basin (Bismarck sea). Mar. Geol. 142, 197-206.

Gebruk, A., Fabri, M.-C., Briand, P., Desbruyeres, D., 2010. Community dynamics over a decadal scale at Logatchev, $14^{\circ} 45^{\prime} \mathrm{N}$, Mid-Atlantic Ridge. Cah. Biol. Mar. 51, 383388.

Genin, A., Dayton, P.K., Lonsdale, P.F., Spiess, F.N., 1986. Corals on seamount peaks provide evidence of current acceleration over deep-sea topography. Nature 322, 59-61.

George, K.H., 2013. Faunistic research on metazoan meiofauna from seamounts - a review. Meiofauna Mar. 20, 1-32.

Glover, A.G., Smith, C.R., 2003. The deep-sea floor ecosystem: current status and prospects of anthropogenic change by the year 2025. Environ. Conserv. 30 (3), 219-241.

Glover, A.G., Smith, C.R., Paterson, G.L.J., Wilson, G.D.F., Hawkins, L., Sheader, M., 2002. Polychaete species diversity in the central Pacific abyss: local and regional patterns, and relationships with productivity. Mar. Ecol. Prog. Ser. 2002 (240), 157-170.

Gollner, S., Riemer, B., Martinez Arbizu, P., Le Bris, N., Bright, M., 2010. Diversity of meiofauna from the 9u50'N East Pacific Rise across a gradient of hydrothermal fluid emissions. PLoS One 5 (8), e12321.

Gollner, S., Fontaneto, D., Martinez Arbizu, P., 2011. Molecular taxonomy confirms morphological classification of deep-sea hydrothermal vent copepods (Dirivultidae) and suggests broad physiological tolerance of species and frequent dispersal along ridges. Mar. Biol. 158, 221-231.

Gollner, S., Miljutina, M., Bright, M., 2013. Nematode succession at deep-sea hy- drothermal vents after a recent volcanic eruption with the description of two dominant species. Org. Divers. Evol. 13, 349-371.

Gollner, S., Govenar, B., Martinez Arbizu, P., Mills, S., Le Bris, N., Weinbauer, M., Shank, T.M., Bright, M., 2015a. Differences in recovery between deep-sea hydrothermal vent and vent-proximate communities after a volcanic eruption. Deep-Sea Res. I 106, 167182.

Gollner, S., Govenar, B., Fisher, C.R., Bright, M., 2015b. Size matters at deep-sea hydrothermal vents: different diversity and habitat fidelity patterns of meio- and macrofauna. Mar. Ecol. Prog. Ser. 520, 57-66.

Gollner, S., Stuckas, H., Kihara, T.C., Laurent, S., Kodami, S., Martinez Arbizu, P., 2016. Mitochondrial DNA analyses indicate high diversity, expansive population growth and high genetic connectivity of vent copepods (Dirivultidae) across different oceans. PLoS One 11 (10), e0163776.

Gooday, A.J., Goineau, A., Voltski, I., 2015. Abyssal foraminifera attached to poly- metallic nodules from the eastern Clarion Clipperton Fracture Zone: a pre- liminary description and comparison with North Atlantic dropstone assemblages. Mar. Biodivers. 45 (3), $391-412$.

Grassle, J.F., 1985. Hydrothermal vent animals: distribution and biology. Science 229 (4715), 713-717.

Grigg, R.W., Malahoff, A., Chave, E.H., Landahl, J., 1987. Seamount benthic ecology and potential environmental impact from managese crust mining in Hawaii. In: Keating, B.H., Fryer, P., Batiza, R., Boehlert, G.W. (Eds.), Seamounts, Islands, and Atolls. Geophysical Monograph, pp. 379-390.

Grimm, V., Wissel, C., 1997. Babel, or the ecological stability discussion: an inventory of terminology and a guide for avoiding confusion. Oecologia 109, 323-334.

Gunderson, L.H., 2000. Ecological resilience-in theory and application. Annu. Rev. Ecol. Syst. 425-439. 
Harris, P.T., Macmillan-Lawler, M., Rupp, J., Baker, E.K., 2014. Geomorphology of the oceans. Mar. Geol. 352, 4-24.

Hein, J.R., 2002. Cobalt-rich ferromanganese crusts: global distribution, composition, origin and research activities. Int. Seabed Auth. Tech. Study 2, 36-89.

Hein, J.R., Koschinsky, A., 2013. Deep-ocean ferromanganese crust and Nodules. In: Holland, H., Turekian, K. (Eds.), Earth Systems and Environmental Sciences, Treatise on Geochemistry 2nd Edition. Elsevier, Amsterdam, pp. 273-291.

Hein, J.R., Petersen, S., 2013. The Geology of cobalt-rich ferromanganese crusts. In: Baker, E., Beaudoin, Y. (Eds.), Deep Sea Minerals: Cobalt-rich Ferromanganese Crusts; A physical, biological, environmental, and technical review. Secretariat of the Pacific Communit, pp. 7-14.

Hein, J.R., Conrad, T.A., Dunham, R.E., 2009. Seamount characteristics and mine-site model applied to exploration and mining lease block selection for cobalt-rich ferromanganese crusts. Mar. Georesources Geotechnol. 27, 160-176.

Herring, P.J., 1990. Light and Life in the Sea“. Cambridge University Press, Cambridge. Cambridge University Press, Cambridge.

Hilario, A., Metaxas, A., Gaudron, S.M., Howell, K.L., Mercier, A., Mestre, N.C., Ross, R.E., Thurnherr, A.M., Young, C., 2015. Estimating dispersal distance in the deep sea: challenges and applications to marine reserves. Front. Mar. Sci. 2 (6), 1-14.

Holdway, D.A., 2002. The acute and chronic effects of wastes associated with offshore oil and gas production on temperature and tropical marine ecological processes. Mar. Pollut. Bull. 44, 185-203.

Holling, C.S., 1973. Resilience and stability of ecological systems. Annu. Rev. Ecol. Syst. 4, 123.

Hornik, K., R. ISBN 3-900051-08-9, 2009: p. http://CRAN.R-project.org/doc/FAQ/R- FAQ.html.

Ingole, B.S., Ansari, Z.A., Rathod, V., Rodrigues, N., 2000. Response of meiofauna to immediate benthic disturbance in the central Indian Ocean basin. Mar. Georesources Geotechnol. 18 (3), 263-272.

Ingole, B.S., Ansari, Z.A., Rathod, V., Rodrigues, N., 2001. Response of deep-sea macrobenthos to a small-scale environmental disturbance. Deep Sea Res. Part II Top. Stud. Oceanogr. 48 (16), 3401-3410.

Ingole, B.S., Pavithran, S., Ansari, Z.A., 2005. Restoration of deep-sea macrofauna after simulated benthic disturbance in the Central Indian Basin. Mar. Georesources Geotechnol. 23 (4), 267-288.

ISA, 2010. A Geological Model of Polymetallic Nodules in the Clarion-Clipperton Fracture Zone. International Seabed Authority Technical Study No. 6, Kingston, Jamaica, p. 75.

Janssen, A., Kaiser, S., Meißner, K., Brenke, N., Menot, L., Martínez Arbizu, P., 2015. A reverse taxonomic approach to assess macrofaunal distribution patterns in abyssal pacific polymetallic Nodule fields. PLoS One 10 (2), e0117790.

Jones, D.O.B., Kaiser, S., Sweetman, A.K., Smith, C.R., Menot, L., Vink, A., et al., 2017. Biological responses to disturbance from simulated deep-sea polymetallic nodule mining. PLoS One 12 (2), e0171750.

Kaiser, M.J., Clarke, K.R., Hinz, H., Austen, M.C.V., Somerfield, P.J., Karakassis, I., 2006. Global analysis of response and recovery of benthic biota to fishing. Mar. Ecol. Prog. Ser. 311, 1-14.

Kim, S.S., Wessel, P., 2011. New global seamount census from altimetry-derived gravity data. Geophys. J. Int. 186, 615-631.

Kitazato, H., Okamoto, T., Responses of foraminiferal distribution in JET - pre- liminary results. Proceedings of International Symposium on Environmental Studies for Deep-Sea Mining, Tokyo, Japan, November 20-21, 1997: p. 31-e320.

Klose, J., Polz, M.F., Wagner, M., Schimak, M.P., Gollner, S., Bright, M., 2015. Endosymbionts escape dead hydrothermal vent tubeworms to enrich the free-living population. PNAS 1-6. 
Knight, R., Roberts, S., 2016. Initial results of batch reactor experiments to deter- mine sulphide oxidation rates and trace metal release under seafloor conditions. Appl. Earth Sci. 125, 88-89.

Kuhn, Cruise participants, T.A., 2015. Low-temperature Fluid Circulation at Sea- mounts and Hydrothermal Pits: heat Flow Regime, Impact on Biogeochemical Processes and its Potential Influence on the Occurrence and Composition of Manganese Nodules in the NE Pacific. SO240/Flum. Cruise Report. BGR, Hann, p. 185.

Larsson, A.I., van Oevelen, D., Purser, A., Thomsen, L., 2013. Tolerance to long-term exposure of suspended benthic sediments and drill cuttings in the cold-water coral Lophelia pertusa. Mar. Pollut. Bull. 70, 176-188.

Laurent, S., Pfeifer, S.P., Settles, M.L., Hunter, S.S., Hardwick, K.M., Ormond, L., Sousa, V.C., Jensen, J.D., Rosenblum, E.B., 2016. The population genomics of rapid adaptation: disentangling signatures of selection and demography in white sands lizards. Mol. Ecol. 25, 306-323.

Leduc, D., Rowden, A.A., Torres, L.G., Nodder, S.D., Pallentin, A., 2015. Distribution of macroinfaunal communities in phosphorite nodule deposits on Chatham Rise, Southwest Pacific: implications for management of seabed mining. Deep Sea Res. Part I 99, 105118.

Lees, K., Pitois, S., Scott, C., Frid, C., Mackinson, S., 2006. Characterizing regime shifts in the marine environment. Fish Fish. 7 (2), 104-127.

Lehmkoester, J., 2014. World Ocean Review 3: Marine Resources e Opportunities and Risks. maribus GmbH, Hamburg, Germany, p. 165.

Levin, S.A., 1999. In: Perseus (Ed.), Fragile Dominion: Complexity and the Commons Reading. Perseus, Massachusetts.

Levin, S.A., Lubchenco, J., 2008. Resilience, robustness, and marine ecosystem-based management. BioScience 58, 27-32.

Levin, L.A., Mendoza, G.F., Konotchick, T., Lee, R., 2009. Macrobenthos community structure and trophic realtionships within active and inactive Pacific hydrothermal sediments. Deep-Sea Res. II 56, 1632-1648.

Levin, L.A., Baco, A.R., Bowden, D.A., Colaco, A., Cordes, E.E., Cunha, M.R.,

Demopoulos, A.W.J., Gobin, J., Grupe, B.M., Le, J., Metaxas, A., Netburn, A.N., Rouse, G.W., Thurber, A.R., Tunnicliffe, V., Van Dover, C.L., Vanreusel, A., Watling, L., 2016a. Hydrothermal vents and methane seeps: rethinking the sphere of influence. Front. Mar. Sci. 3-72.

Levin, L.A., Mengerink, K., Gjerde, K.M., Rowden, A.A., Van Dover, C.L., Clark, M.R., RamirezLlodra, E., Currie, B., Smith, C.R., Satoi, K.N., Galloi, N., Sweetman, A.K., Lily, H., Armstrong, C.W., Brider, J., 2016b. Defining "serious harm" to the marine environment in the context of deepseabed mining. Mar. Policy 74, 245-259.

Loewe, W.H., Allendorf, F.W., 2010. What can genetics tell us about population connectivity? Mol. Ecol. 19, 3038-3051.

Lotze, H.K., Coll, M., Magera, A.M., Ward-Paige, C., Airoldi, L., 2011. Recovery of marine animal populations and ecosystems. TREE 26 (11), 595-605.

Madureira, P., Brekke, H., Cherkashov, G., Rovere, M., 2016. Exploration of poly- metallic nodules in the Area: reporting practices, data management and transparency. Mar. Policy 70, 101-107.

Mahatma, R., 2009. Meiofauna Communities of the Pacific Nodule Province: Abundance, Diversity and Community Structure. Carl von Ossietzky Universitaet Oldenburg, p. 142.

Marcus, J., Tunnicliffe, V., Butterfield, D.A., 2009. Post-eruption succession of macrofaunal communities at diffuse flow hydrothermal vents on Axial Volcano, Juan de Fuca Ridge, Northeast Pacific. Deep-Sea Res. II 56, 1586-1598.

Marsh, L., Copley, J.T., Huvenne, V.A.I., Linse, K., Reid, W.D.K., Rogers, A.D., et al., 2012. Microdistribution of faunal assemblages at deep-sea hydrothermal vents in the Southern Ocean. PLoS One 7 (10), e48348.

Mayer-Pinto, M., Underwood, A.J., Tolhurst, T., Coleman, R.A., 2010. Effects of metals on aquatic assemblages: what do we really know? J. Exp. Mar. Biol. Ecol. 391, 1-9. 
McClain, C.R., Lundsten, L., Ream, M., Barry, J., De Vogelaere, A., 2009. Endemicity, biogeography, composition and community structure on a Northeast Pacific seamount. PLoS One 4 (1), e4141.

McLusky, D.S., Bryant, V., Campbell, R., 1986. The effects of temperature and salinity on the toxicity of heavy metals to marine and estuarine invertebrates. Oceanogr. Mar. Biol. Annu. Rev. 24, 481-520.

Mestre, N.C., Calado, R., Soares, A.M.V.M., 2014. Exploitation of deep-sea resources: the urgent need to understand the role of high pressure in the toxicity of chemical pollutants to deep-sea organisms. Environ. Pollut. 185, 369-371.

Mewes, K., Mogollo'n, J.M., Picard, A., Rühlemann, C., Kuhn, T., No€then, K., Kasten, S.,

2014. The impact of depositional and biogeochemical processes on small scale variations in nodule abundance in the Clarione Clipperton Fracture Zone. Deep-Sea Res. 191, 125141.

Miljutin, D.M., Gunnar, G., Miljutina, M., Mokievsky, V.O., Fonseca-Genevois, V., Esteves, A.M., 2010. The state of knowledge on deep-sea nematode taxonomy: how many valid species are known down there? Mar. Biodivers. 40, 143-159.

Miljutin, D.M., Miljutina, M.A., Martinez Arbizu, P., Galeron, J., 2011. Deep-sea nematode assemblage has not recovered 26 years after experimental mining of polymetallic nodules (Clarion-Clipperton Fracture Zone, Tropical Eastern Pacific). Deep-Sea Res. I 58, 885-897.

Miljutina, M.A., Miljutin, D.M., Mahatma, R., Gale'ron, J., Miljutina, M.A., Miljutin, D.M., Mahatma, R., Gallron, J., 2010. Deep-sea nematode assemblages of the ClarionClipperton Nodule province (tropical North-eastern pacific), 2010 Mar. Biodivers. 40 (1), 1-15.

Miller, K., Williams, A., Rowden, A.A., Knowles, C., Dunshea, G., 2010. Conflicting estimates of connectivity among deep-sea coral populations. Mar. Ecol. 31, 144-157.

Moalic, Y., Desbruyeres, D., Duarte, C.M., Rozenfeld, A.F., Bachraty, C., Arnaud- Haond, S., 2012. Biogeography revisted with network theory: retracting the history of hydrothermal vent communities. Syst. Biol. 61 (1), 127-137.

Morato, T., Hoyle, S.D., Allain, V., Nicol, S.J., Seamounts are hotspots of pelagic biodiversity in the open ocean. Proceedings of the National Academy of Sciences of the United States of America, 2010. 107: p. 9707-9711.

Moreau, S., Vidussi, F., Ferreyra, G., Mostajir, B., 2016. Ecological impacts of ultraviolet-B radiation on marine ecosystems. In: Solan, M., Whiteley, N.M. (Eds.), Stressors in the Marine Environment. Oxford University Press, Oxford, pp. 261-281.

Morgan, N.B., Cairns, S., Reiswig, H., Baco, A.R., 2015. Benthic megafaunal commu- nity structure of cobalt-rich manganese crusts on Necker Ridge. Deep Sea Res. Part I Oceanogr. Res. Pap. 104, 92-105.

Müller, P.J., Hartmann, M., Suess, E., 1988. The chemical environment of pelagic sediments. In: Halbach, P., Friedrich, G., von Stackelberg, U. (Eds.), The Manganese Nodule Belt of the Pacific Ocean: Geological, Environment, Nodule Formation, and Mining Aspects. Enke Verlag, Stuttgart, pp. 70-90.

Mullineaux, L.S., 1987. Organisms living on manganese nodules and crusts: distribution and abundance at three North Pacific sites. Deep-Sea Res. 34 (2), 165-184.

Mullineaux, L.S., Butman, C.A., 1990. Recruitment of encrusting benthic in- vertebrates in boundary-layer flows: a deep-water experiment on Cross Seamount. Limnol. Oceanogr. 35 (2), 409-423.

Mullineaux, L.S., Peterson, C.H., Micheli, F., Mills, S.W., 2003. Successional mecha- nism varies along a gradient in hydrothermal fluid flux at deep-sea vents. Ecol. Monogr. 73 (4), 523-542.

Mullineaux, L.S., Micheli, F., Peterson, C.H., Lenihan, H.S., Markus, L., 2009. Imprint of past environmental regimes on structure and succession of a deep-sea hydrothermal vent community. Oecologia 161 (2), 387-400.

Mullineaux, L.S., Adams, D.K., Mills, S.W., Beaulieu, S.E., 2010. Larvae from afar colonize deep-sea hydrothermal vents after a ctastrophic eruption. PNAS 107 (17), 7829-7834. 
Mullineaux, L.S., Le Bris, N., Mills, S.W., Henri, P., Bayer, S.R., Secrist, R.G., Siu, N., 2012. Detecting the influence of initial pioneers on succession at deep-sea vents. PLoS One 7 (12), e50015.

Nakajima, R., Yamamoto, H., Kawagucci, S., Takaya, Y., Nozaki, T., Chen, C., et al., 2015. Post drilling changes in seabed landscape and megabenthos in a deep-sea hydrothermal system, the Iheya North field, Okinawa trough. PLoS One 10 (4), e0123095.

Nautilus Minerals, N.L., 2008. Main Report. Environmental Impact Statement: Solwara 1 Project, vol. A, p. 226.

Netto, S.A., Gallucci, F., Fonseca, G., 2009. Deep-sea meiofauna response to syntheticbased drilling mud discharge off SE Brazil. Deep-Sea Res. II 56, 41e49. Norkko, A., Rosenberg, R., Thrush, S.F., Whitlatch, R.B., 2006. Scale- and intensity- dependent disturbance determines the magnitude of opportunistic response. J. Exp. Mar. Biol. Ecol. 330 (1), 195-207.

Norse, E.A., Brooke, S., Cheung, W.W.L., Clark, M.R., Ekeland, I., Froese, R.,

Gjerde, K.M., Haedrich, R.L., Heppell, S.S., Morato, T., Morgan, L.E., Pauly, D., Sumaila, R., Watson, R., 2012. Sustainability of deep-sea fisheries. Mar. Policy 36 (2), 307-320.

Oebius, H.U., Becker, H.J., Rolinski, S., Jankowski, J.A., 2001. Parametrization Eval. Mar. Environ. impacts Prod. by deep-sea manganese nodule Min. Deep Sea Res. Part II Top. Stud. Oceanogr. 48 (17e18), 3453-3467.

Olafsson, E., 2003. Do macrofauna structure meiofauna assemblages in marine softbottoms? Vie Milieu 53 (4), 249-265.

O'Hara, T.D., Tittensor, D.P., 2010. Environmental drivers of ophiuroid species richness on seamounts. Mar. Ecol. 31 (1), 26-38.

Packmor, J.F., Mueller, F., George, K.H., 2015. Oceanic islands and seamounts as staging posts for Copepoda Harpacticoida (Crustacea) - shallow-water Para-mesochridae Lang, 1944 from the North-East Atlantic Ocean, including the (re-) description of three species and one subspecies from the Madeiran Archipelago. Prog. Oceanogr. 131, 5981.

Palumbi, S.R., McLeod, K.L., Gruenbaum, D., 2008. Ecosystems in action: lessons from marine ecology about recovery, resistance, and reversibilty. BioScience 58 (1), 33-42.

Parker, T., Tunnicliffe, V., 1994. Dispersal strategies of the biota on an oceanic seamount: implications for ecology and biogeography. Biol. Bull. 187 (3), 336-345.

Paterson, G.L.J., Menot, L., Colaço, A., Glover, A.G., Gollner, S., Kaiser, S., Gebruk, A.V., Janssen, A., Silva, M.C.A., Janssen, F., Sahling, H., Felden, J., Martinez, P.A., 2015. Biogeography and connectivity in deep-sea habitats with mineral resource potentialgap analysis. MIDAS Deliv. 4.2, 45.

Petersen, S., Kratschell, A., Augustin, N., Jamieson, J., Hein, J.R., Hannington, M.D., 2016. News from the seabed-Geological characteristics and resource potential of deepsea mineral resources. Mar. Policy 70, 175-187.

Peterson, G., Allen, C.R., Holling, C.S., 1998. Ecological resilience, biodiversity, and scale. Ecosystems 1, 6-18.

Pham, C.K., Vandeperre, F., Menezes, G., Porteiro, F., Isidro, F., Morato, T., 2015. The importance of deep-sea vulnerable marine ecosystems for demersal fish in the Azores. Deep-Sea Res. I 96, 80-88.

Pitcher, T.J., Morato, T., Hart, P.J., Clark, M.R., Haggan, N., Santos, R.S., 2007. Sea- mounts: Ecology, Fisheries \& Conservation. John Wiley \& Sons.

Pitcher, T.J., Clark, M.R., Morato, T., Watson, R., 2010. Seamount fisheries: do they have a future? Oceanography 23 (1), 134-144.

Plum, C., Pradillon, F., Fujiwara, Y., Sarrazin, J., 2017. Copepod colonization of organic and inorganic substrata at a deep-sea hydrothermal vent site on the Mid- Atlantic Ridge. Deep Sea Res. II 137, 335-348.

Radziejewska, T., 2002. Responses of deep-sea meiobenthic communities to sedi- ment disturbance simulating effects of polymetallic nodule mining. Int. Rev. Hydrobiology 87 (4), 457-477. 
Radziejewska, T., Stoyanova, V., 2000. Abyssal epibenthic megafauna of the ClarionClipperton area (NE Pacific): changes in time and space versus anthropogenic environmental disturbance. Oceanol. Stud. Gdansk 29 (2), 83-101.

Ramirez-Llodra, E., Brandt, A., Danovaro, R., De Mol, B., Escobar, E., German, C.R., Levin, L.A., Martinez Arbizu, P., Menot, L., Buhl-Mortensen, P., Narayanaswamy, B.E., Smith, C.R., Tittensor, D.P., Tyler, P.A., Vanreusel, A., Vecchione, M., 2010. Deep, diverse and definitely different: unique attributes of the world's largest ecosystem. Biogeosciences vol. 7, 2851-2899.

Ramirez-Llodra, E., Tyler, P.A., Baker, M.C., Bergstad, O.A., Clark, M.R., Escobar, E., Levin, L.A., Menot, L., Rowden, A.A., Smith, C.R., Van Dover, C.L., 2011. Man and the last great wilderness: human impact on the deep sea. PLoS One 6 (7), e22588.

Richer de Forges, B., Koslow, J.A., Poore, G.C.B., Richer de Forges, B., Koslow, J.A., Poore, G.C.B., 2000. Diversity and endemism of the benthic seamount fauna in the southwest Pacific. Nature 2000 (405), 944-947.

Rinke, C., Lee, R.W., 2009. Pathways, activities an dthermal stability of anaerobic and aerobic enzymes in thermophilic vent paralvinellid worms. Mar. Ecol. Prog. Ser. 382, 99-112.

Roark, E.B., Guilderson, T.P., Dunbar, R.B., Ingram, B.L., 2006. Radiocarbon-based ages and growth rates of Hawaiian deep-sea corals. Mar. Ecol. Prog. Ser. 327, 1-14.

Roberts, C.M., 2002. Deep impact: the rising toll of fishing in the deep sea. Trends Ecol. Evol. 17 (5), 242-245.

Rowden, A.A., Dower, J.F., Schlacher, T.A., Consalvey, M., Clark, M.R., 2010. Paradigms in seamount ecology: fact, fiction and future. Mar. Ecol. 31, 226-241.

Samadi, S., Bottan, L., Macpherson, E., De Forges, B.R., Boisselier, M.C., 2006. Seamount endemism questioned by the geographic distribution and population genetic structure of marine invertebrates. Mar. Biol. 149 (6), 1463-1475.

Santos, M.F.L., Lana, P.C., Silva, J., Fachel, J.G., Pulgati, F.H., 2009. Effects of non- aqueous fluids cuttings discharge from exploratory drilling activities on the deep-sea macrobenthic communities. deep Sea Res. II 56, 32-40.

Schaaning, M.T., Trannum, H.C., Øxnevad, S., Carroll, J., Blake, T., 2008. Effects of drill cuttings on biogeochemical fluxes and macrobenthos of marine sediments.J. Exp. Mar. Biol. Ecol. 361, 49-57.

Schlacher, T.A., Baco, A.R., Rowden, A.A., O'Hara, T.D., Clark, M.R., Kellet, C., Dower, J.F., 2013. Seamount benthos in a cobalt-rich crust region of the central Pacific: conservation challenges for future seabed mining. Divers. Distributions 1-12.

Schlacher, T.A., Baco, A.R., Rowden, A.A., O'Hara, T.D., Clark, M.R., Kelley, C., Dower, J.F., 2014. Seamount benthos in a cobalt-rich crust region of the central Pacific: conservation challenges for future seabed mining. Divers. distributions 20 (5), 491 502.

Sen, A., Kim, S., Miller, A.J., Hovey, K.J., Hourdez, S., Luther, G.W., Fisher, C.R., 2016. Peripheral communities of the Eastern Lau Spreading Center and Valu Fa Ridge: community composition, temporal change and comparison to near-vent com- munities. Mar. Ecol. http://dx.doi.org/10.1111/maec.12313.

Shank, T.M., 2010. Seamounts: deep-ocean laboratories of faunal connectivity, evolution, and endemism. Oceanography 23 (1), 108-122.

Shank, T.M., Fornari, D.J., Von Damm, K.L., Haymon, R.M., Lutz, R.A., 1998. Temporal and spatial patterns of biological community development at nascent deep-sea hydrothermal vents (9o 50'N, East Pacific Rise). Deep-Sea Res. Part II 45, 465-515.

Shirayama, Y., Fukushima, T., Responses of a meiobenthos community to rapid resedimentation. Proceedings of International Symposium on Environmental Studies for Deep-Sea Mining, Tokyo, Japan, November 20-21, 1997: p. 1187-196.

Simpson, S.L., Spadaro, D.A., 2016. Bioavailability and chronic toxicity of metal sulfide minerals to benthic marine invertebrates: implications for deep sea exploration, mining and Tailings disposal. Environ. Sci. Technol. 50 (7), 4061-4070.

Singh, R., Miljutin, D.M., Vanreusel, A., Radziejewska, T., Miljutina, M.M., Tchesunov, A., Bussau, C., Galtsova, V., Martinez Arbizu, P., 2016. Nematode communities inhabiting 
the soft deep-sea sediment in polymetallic nodule fields: do they differ from those in the nodule-free abyssal areas? Mar. Biol. Res. 12 (4).

Smith, P.J., McMillan, P.J., Bull, B., McVeagh, S., Gaffney, P.M., Chow, S., 2002. Genetic and meristic variation in black and smooth oreos in the New Zealand EEZ. N. Z. J. Mar. Freshw. Res. 36 (4), 737-750.

Smith, P.J., McVeagh, S.M., Mingoia, J.T., France, S.C., 2004. Mitochondrial DNA sequence variation in deep-sea bamboo coral (Keratoisidinae) species in the southwest and northwest Pacific Ocean. Mar. Biol. 144, 253-261.

Smith, C.R., Levin, L.A., Koslow, A., Tyler, P.A., Glover, A.G., 2008. The near future of the deep-sea floor ecosystems. In: Polunin, N.V.C. (Ed.), Aquatic Ecosystems: Trends and Global Prospects. Cambridge University Press, New York, p. 334.

Smolenski, A.J., Ovenden, J.R., White, R.W.G., 1993. Evidence of stock separation in Southern Hemisphere (Hoplostethus atlanticus, Trachichyidae) from restrictionenzyme analysis of mitochondrial DNA. Mar. Biol. 116, 219-230.

Sokolova, I.M., Frederich, M., Bagwe, R., Lannig, G., Sukhotin, A.A., 2012. Energy homeostasis as an integrative tool for assessing limits of environmental stress tolerance in aquatic invertebrates. Mar. Environ. Res. 79, 1-15.

Sousa, V., Hey, J., 2013. Understanding the origin of species with genome-scale data: modelling gene flow. Nat. Rev. Genet. 14, 404-414.

SPC, 2013. In: Baker, E., Beaudoin, Y. (Eds.), Deep Sea Minerals: Sea-floor Massive Sulphides, a Physical, Biological, Environmental, and Technical Review, 1A. Secretariat of the Pacific Community.

SPC, 2013. In: Baker, E., Beaudoin, Y. (Eds.), Deep Sea Minerals: Manganese Nodules, a Physical, Biological, Environmental, and Technical Review, 1B. Secretariat of the Pacific Community.

SPC, 2013. In: Baker, E.B., Y. (Eds.), Deep Sea Minerals: Cobalt-rich Ferromanganese Crusts, a Physical, Biological, Environmental, and Technical Review, 1C. Secretariat of the Pacific Community.

Stanley, J.A., Jeffs, A.G., 2016. Ecological impacts of anthropogenic underwater noise. In: Solan, M., Whiteley, N.M. (Eds.), Stressors in the Marine Environment. Ox- ford University Press, Oxford, pp. 282-297.

Stockley, B.M., Menezes, G., Pinho, M.R., Rogers, A.D., 2005. Genetic population structure of the black-spot sea bream (Pagellus bogaraveo) from the NE Atlantic. Mar. Biol. 146, 793-804.

Suding, K.N., Gross, K.L., Houseman, G.R., 2004. Alternative states and positive feedbacks in restoration ecology. Trends Ecol. Evol. 19 (1), 46-53.

Swaddling, A., 2016. Environmental management considerations for deep sea mining. Mining (March 4).

Teixeira, S., Cambon-Bonavita, M.-A., Serrao, E.A., Desbruyeres, D., Arnaud-Haond, S., 2010. Recent population expansion and connectivity in the hydrothermal shrimp Rimicaris exoculata along the Mid-Atlantic Ridge. J. Biogeogr. 1-11.

Teixeira, S., Serrao, E.A., Arnaud-Haond, S., 2012. Panmixia in a fragmented and unstable environment: the hydrothermal vent shrimp Rimicaris exoculata disperses extensively along the Mid-Atlantic Ridge. PLoS One 7 (6), e38521.

Tempera, F., Atochi, E., Amorim, J., Gomes-Pereira, J., Goncalves, J., 2013. Atlantic Area Marine Habitats. Adding New Macaronesian Habitat Types from the Azores to the EUNIS Habitat Classification. Technical Report No. 4/2013- MeshAtlantic, IMAR/DOPUAc, Horta.

Thiel, H., Schriever, G., Bussau, C., Borowski, C., 1993. Manganese nodule crevice fauna. Deep-Sea Res. 34, 419-423.

Tolstoy, M., Cowen, J.P., Baker, E.T., Fornari, D.J., Rubin, K.H., Shank, T.M., Waldhauser, F., Bohnenstiehl, D.R., Forsyth, D.W., Holmes, R.C., Love, B., Perfit, M.R., Weekly, R.T., Soule, S.A., Glazer, B., 2006. A sea-floor spreading event captured by seismometers. Science 314, 1920-1922. 
Trannum, H.C., Nilsson, H.C., Schaaning, M.T., Øxnevad, S., 2010. Effects of sedimentation from water-based drill cuttings and natural sediment on benthic macrofaunal community structure and ecosystem processes. J. Exp. Mar. Biol. Ecol. 383, 111-121.

Trueblood, D.D., Ozturgut, E., 1997. The benthic impact experiment: a study of the ecological impacts of deep seabed mining on Abyssal Benthic Communities. In: The Seventh International Offshore and Polar Engineering Conference, Honolulu, USA, May 25-30 1997. International Society of Offshore and Polar Engineers.

Tunnicliffe, V., 1992. The nature and origin of the modern hydrothermal vent fauna. PALAIOS 7, 338-350.

Tunnicliffe, V., Embley, R.W., Holden, J.F., Butterfield, D.A., Massoth, G.J., Juniper, S.K., 1997. Biological colonization of new hydrothermal vents following an eruption on Juan de Fuca Ridge. Deep-Sea Res. I 44, 1627-1644.

Van Dover, C.L., 2000. The Ecology of Hydrothermal Vents. Princeton University Press, Princeton New Jersey, p. 424.

Van Dover, C.L., 2011. Mining seafloor massive sulphides and biodiversity: what is at risk? J. Mar. Sci. 68 (2), 341-348.

Van Dover, C.L., 2014. Impacts of anthropogenic disturbances at deep-sea hydro- thermal vent ecosystems: a review. Mar. Environ. Res. 102, 59-72.

Van Dover, C.L., Szuts, E.Z., Chamberlain, S.C., Cann, J.R., 1989. A novel eye in 'eyeless" shrimp from the hydrothermal vents of the Mid-Atlantic Ridge. Nature 337, 458-460.

Van Dover, C.L., Aronson, J., Pendleton, L., Smith, S., Arnaud-Haond, S., Moreno- Mateos, D., Barbier, E., Billett, D., Bowers, K., Danovaro, R., Edwards, A., Kellert, S., Moratom, T., Pollard, E., Rogers, A.,Warner, R., 2014. Ecological restoration in the deep sea:desiderata. Mar. Policy 98-106.

Vanreusel, A., Hilario, A., Ribeiro, P.A., Menot, L., Arbizu, P.M., 2016. Threatened by mining, polymetallic nodules are required to preserve abyssal epifauna. Sci. Rep. 6, 26808.

Veillette, J., Juniper, S.K., Gooday, A.J., Sarrazin, J., 2007a. Influence of surface texture and microhabitat heterogeneity in structuring nodule faunal communities. Deep Sea Res. Part I Oceanogr. Res. Pap. 54 (11), 1936-1943.

Veillette, J., Sarrazin, J., Gooday, A.J., Galeron, J., Caprais, J.C., Vangriesheim, A., Juniper, S.K., 2007b. Ferromanganese nodule fauna in the Tropical North Pacific Ocean: species richness, faunal cover and spatial distribution. Deep Sea Res. Part I Oceanogr. Res. Pap. 54 (11), 1912-1935.

Von Damm, K.L., 1995. Controls on the chemistry and temporal variability of seafloor hydrothermal fluids. In: Humphris, S.E., Zierenberg, R.A., Mullineaux, L.S., Thomson, R.E. (Eds.), Seafloor Hydrothermal Systems: Physical, Chemical, Biological and Geological Interactions. American Geophysical Union, Washington,DC

Von Damm, K.L., 2004. Evolution of the Hydrothermal System at East Pacific Rise 9o 50'N: Geochemical Evidence for Changes in the Upper Oceanic Crust. American Geophysical Union, 10.1029: pp. 1-20.

Vopel, K., Thiel, H., 2001. Abyssal nematode assemblages in physically disturbed and adjacent sites of the eastern equatorial Pacific. Deep-Sea Res. part II 48, 3795-3808.

Vrijenhoek, R.C., 2010. Genetic diversity and connectivity of deep-sea hydrothermal vent metapopulations. Mol. Ecol. 19, 4391-4411.

Walker, B., Holling, C.S., Carpenter, S.R., Kinzig, A., 2004. Resilience, adaptability and transformability in social-ecological systems. Ecol. Soc. 9 (2). http://www. ecologyandsociety.org/vol9/iss2/art5/.

Wang, C.S., Liao, L., Xu, H.X., Xu, X.W., Xu, M., Zhu, I. Z., 2010. Bacterial diversity in the sediment from polymetallic Nodule fields of the Clarion-Clipperton fracture Zone. J. Microbiol. 48, 573-585.

Watson, R., Morato, T., 2004. Exploitation patterns in seamount fisheries: a pre- liminary analysis. In: Morato, T., Pauly, D. (Eds.), Seamounts: Biodiversity and Fisheries. Fisheries Centre Research Report, 12(5).

Weaver, P., 2016. Biodiversity Implications of Deep-sea Mining Activities. Secretariat of the Convention on Biological Diversity, p. 70. 
Wedding, L.M., Reiter, S.M., Smith, C.R., Gjerde, K.M., Kittinger, J.M.,

Friedlander, A.M., Gaines, S.D., Clark, M.R., Thurnherr, A.M., Hardy, S.M., Crowder, L.B., 2015. Managing mining of the deep seabed:Contracts are being granted, but protections are lagging. Science 349 (6244), 144-145.

Wilcoxon, F., 1945. Individual comparisons by ranking methods. Biom. Bull. 1, 80-83.

Williams, A., Schlacher, T.A., Rowden, A.A., Althaus, F., Clark, M.R., Bowden, D.A., Stewart, R., Bax, N.J., Consalvey, M., Kloser, R.J., 2010. Seamount megabenthic assemblages fail to recover from trawling impacts. Mar. Ecol. 31, 183-199.

Yesson, C., Clark, M.R., Taylor, M., Rogers, A.D., 2011. The global distribution of seamounts based on 30-second bathymetry data. Deep Sea Res. Part I 58 (4), 442-453.

Zeppilli, D., Bongiorni, L., Serrao Santos, R., Vanreusel, A., 2014. Changes in Nematode communities in different physiographic sites of the condor seamount (North-East atlantic ocean) and adjacent sediments. PLoS ONE 9 (12), e115601. 


\section{Figures}

Fig. 1. Examples of deep-sea minerals. a. Polymetallic sulphide sample from Edmond vent field in the Indian Ocean (photo courtesy BGR). b. Cobalt-rich ferromanganese crust from the Great Meteor seamount chain (photo courtesy EMEPC). c. Polymetallic nodule (size $\sim 12 \mathrm{~cm}$ in length) from the Clarion-Clipperton Fracture Zone (photo courtesy of S. Kaiser, SGN).
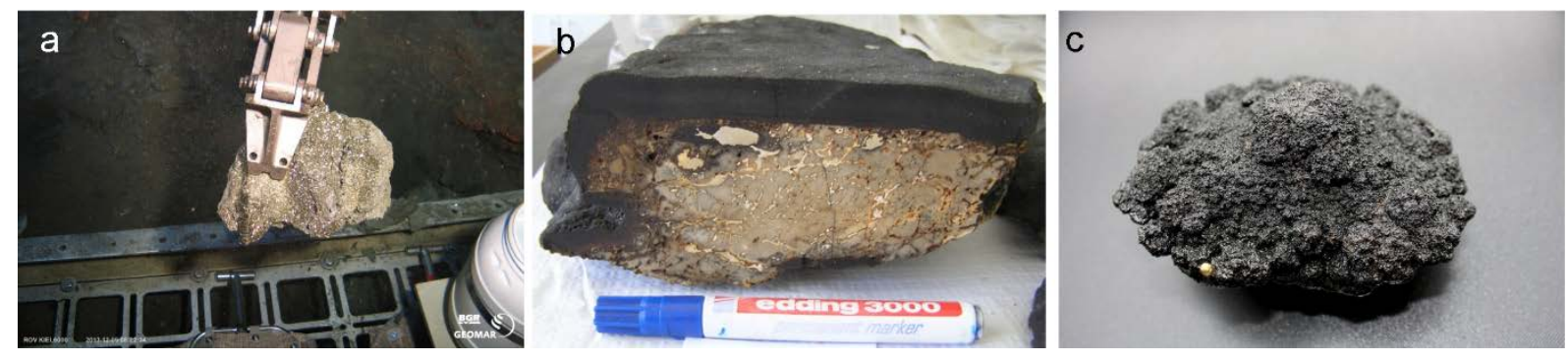
Fig. 2. Examples of ecosystems/habitats and associated biological communities potentially affected by mineral mining. a. Active black smoker (Kairei; Indian Ocean). b. Vent field colonized by shrimps, anemones, and mussels (Kairei; Indian Ocean). c. Inactive vent field (Edmond; Indian Ocean). d. Pillow lava in vent peripheral areas (adjacent to Sonne; Indian Ocean). e. Coral gardens on inactive vent/seamount (near Menez Gwen, Atlantic; photo courtesy of Missao Seahma). f. Nodule field (Clarion-Clipperton Fracture Zone, Pacific). Photos a-d, f of courtesy of GEOMAR.
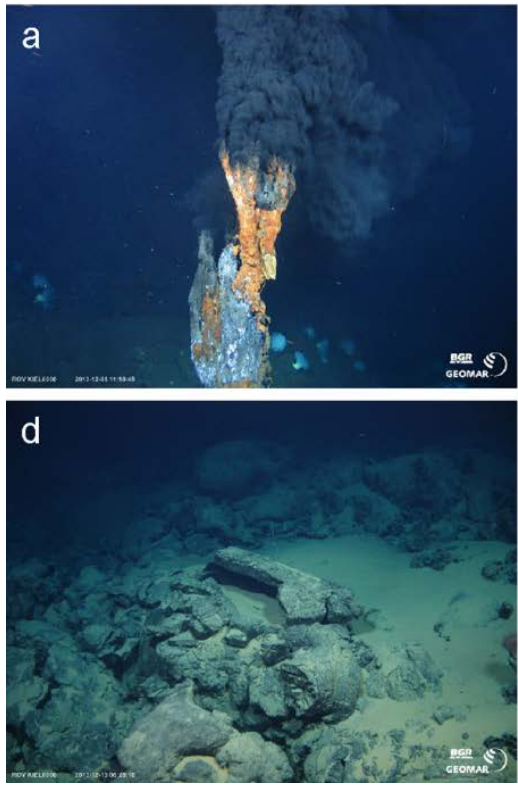
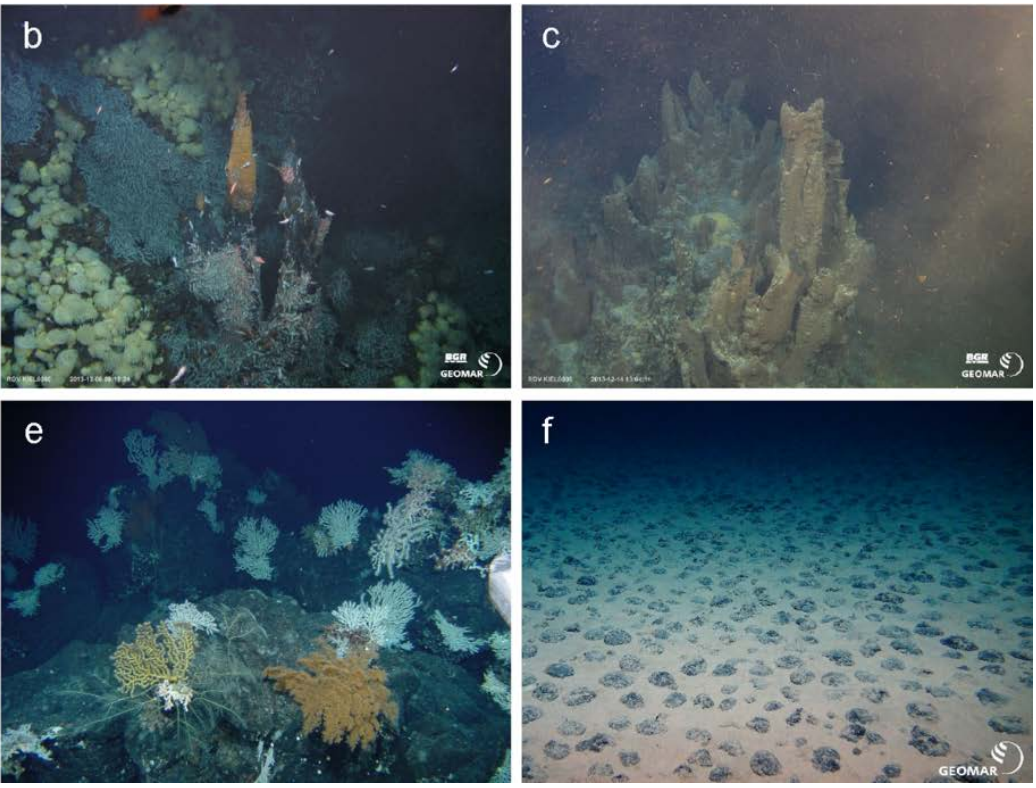
Fig. 3. a. Mining scenario for polymetallic sulphides at hydrothermal vents. b. Bulk cutter for sulphide mining (photo courtesy Nautilus Minerals). c. Collection machine for sulphide mining (photo courtesy Nautilus Minerals). d. Mining scenario for cobalt-rich ferromanganese crusts at seamounts. e. Mining scenario for polymetallic nodules on abyssal plains. All scenarios show the marine environment, seafloor production tools and sediment plumes, riser and lifting system to the vessel, and release of mineral washings.
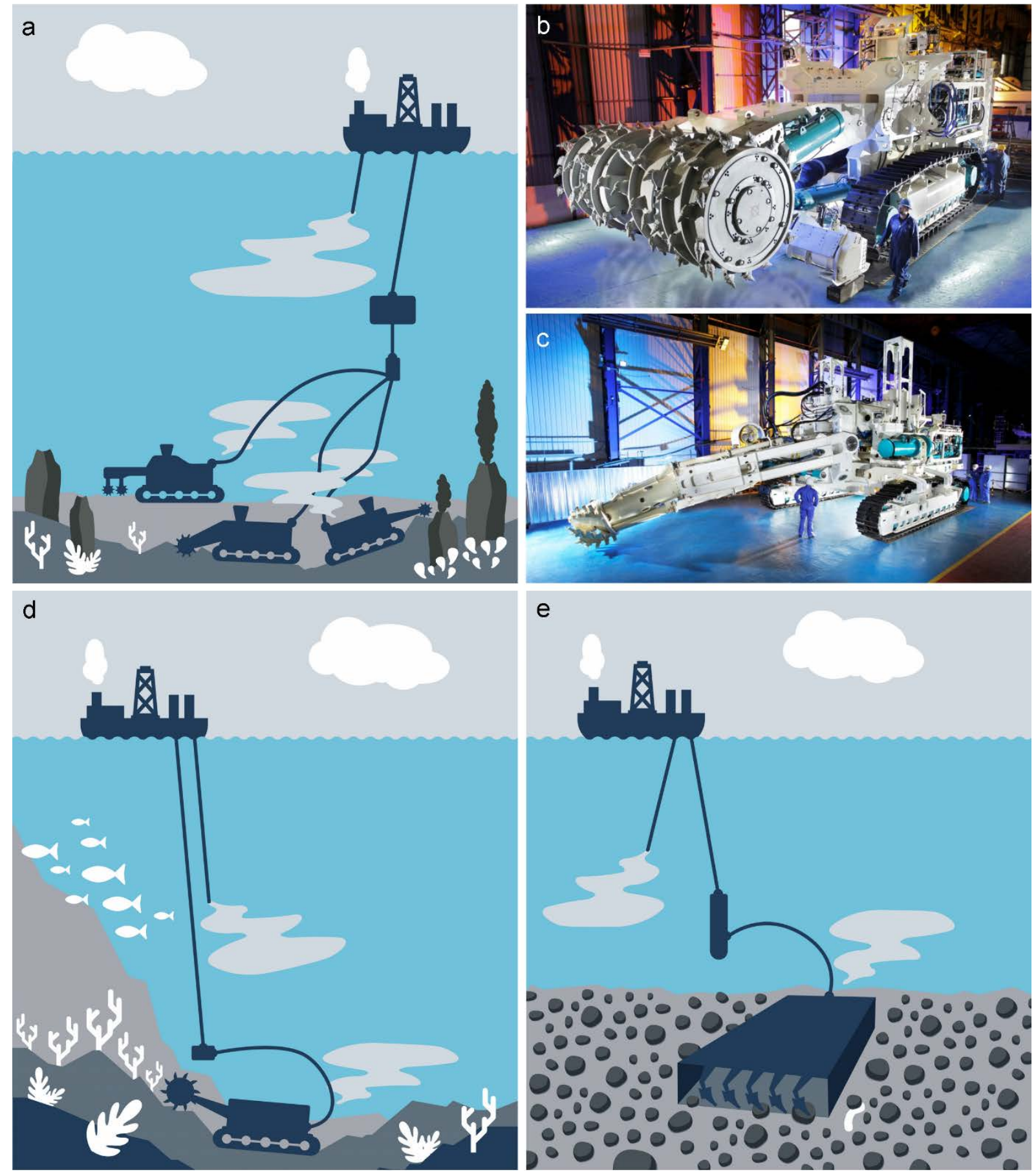
Fig. 4. Mean recovery (\%) relative to pre-disturbance faunal density and diversity at active hydrothermal vents. For data see Appendix A. EPR: East Pacific Rise. JFR: Juan de Fuca Ridge.
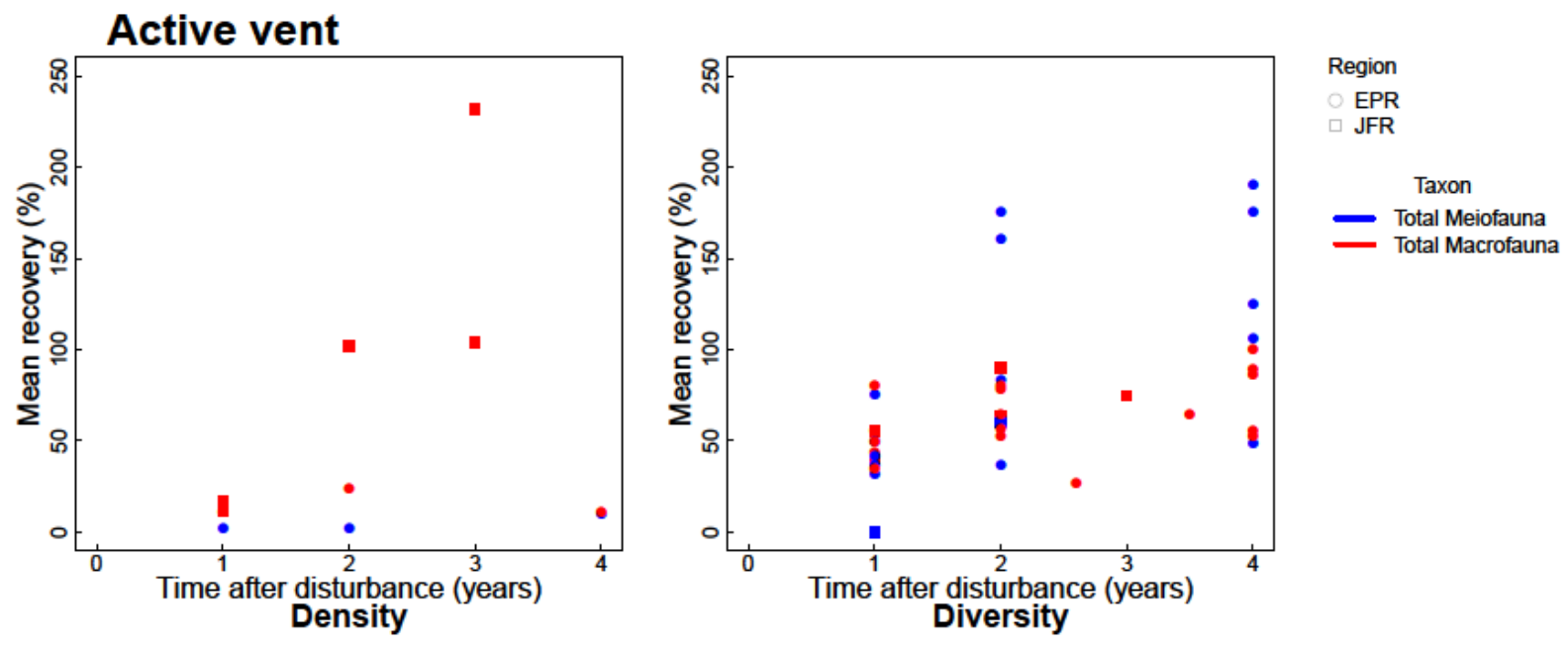
Fig. 5. Absolute numbers and standard deviation of density and diversity values measured predisturbance (indicated as P) and after disturbance (in years) for meiofauna and macrofauna at active hydrothermal vents. For data and metric see Appendix A. Circles: mobile taxa. Triangle: sessile taxa. Square: mixed taxa (sessile and mobile).

\section{Active vent}
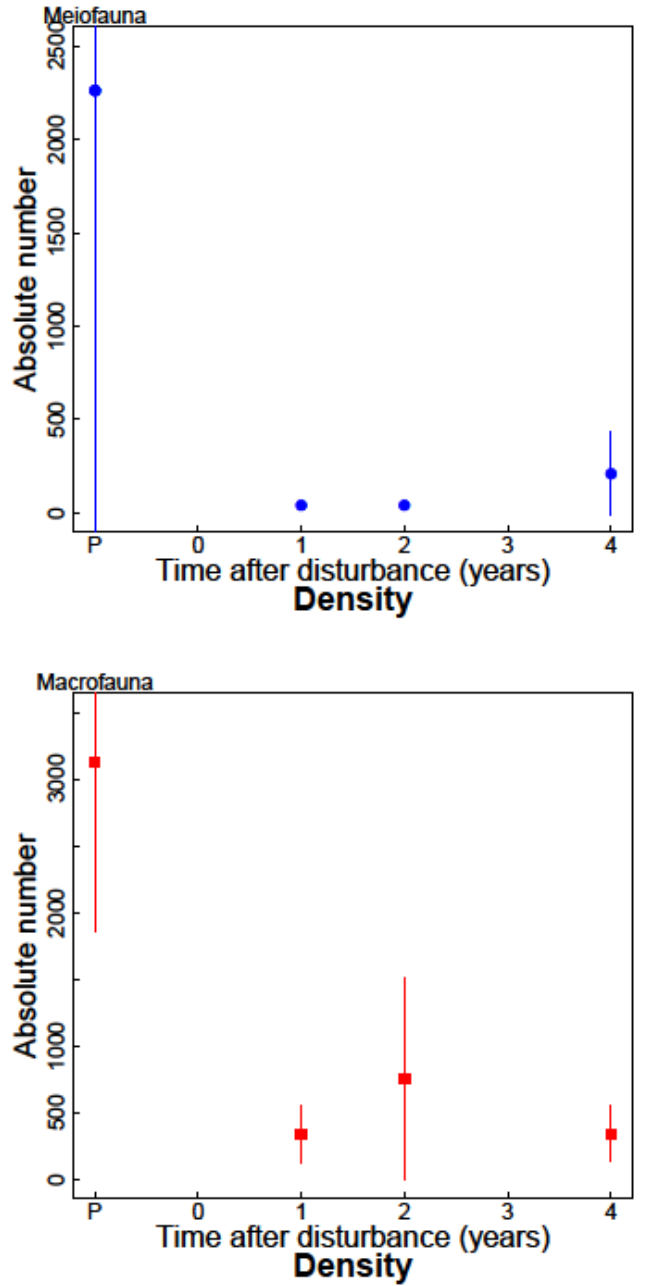
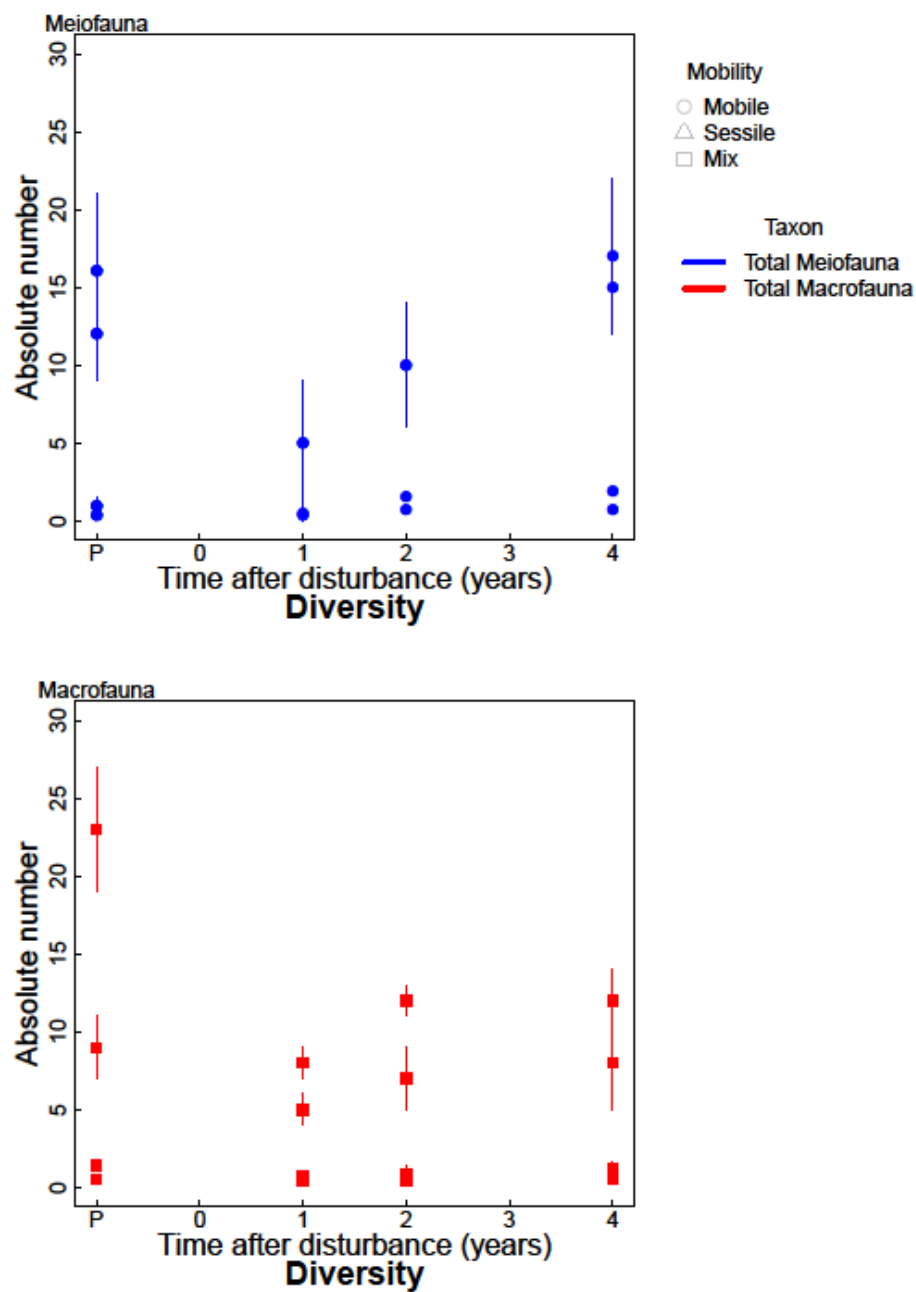
Fig. 6. Results of Wilcoxon rank sum tests for differences in mean recovery (\%) relative to pre-disturbance diversity and density between meio- and macrofauna at active vents at the East Pacific Rise (EPR) and at the Juan de Fuca (JFR), and in the vent periphery (at EPR). Pvalues are given for significant differences.

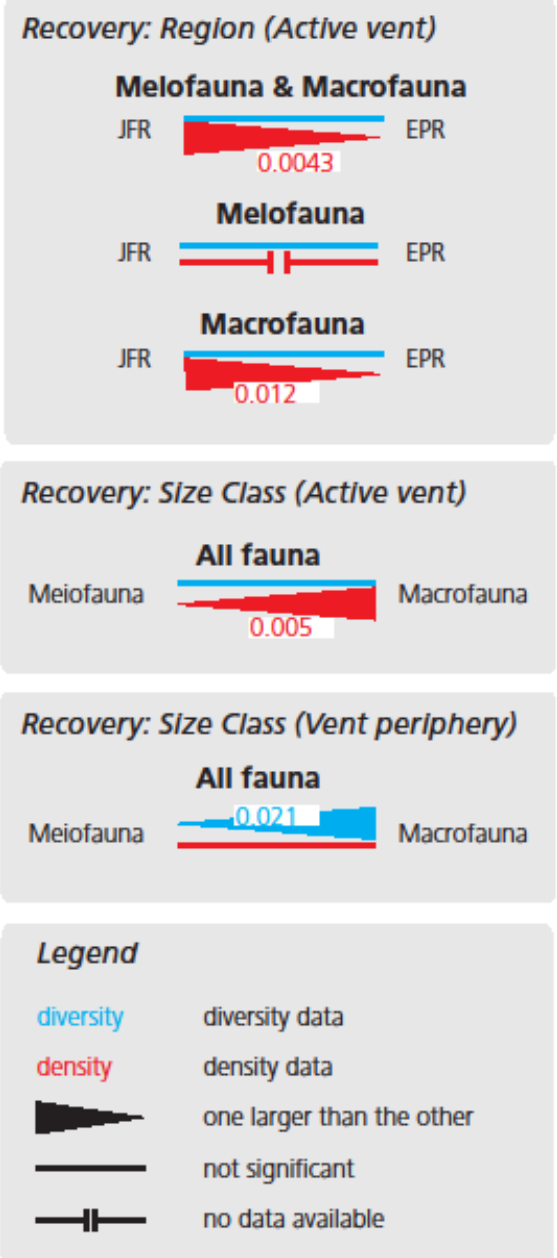


Fig. 7. Mean recovery (\%) relative to pre-disturbance faunal density and diversity in the vent periphery. Circles: mobile taxa. Triangle: sessile taxa. Square: mixed taxa (sessile and mobile).
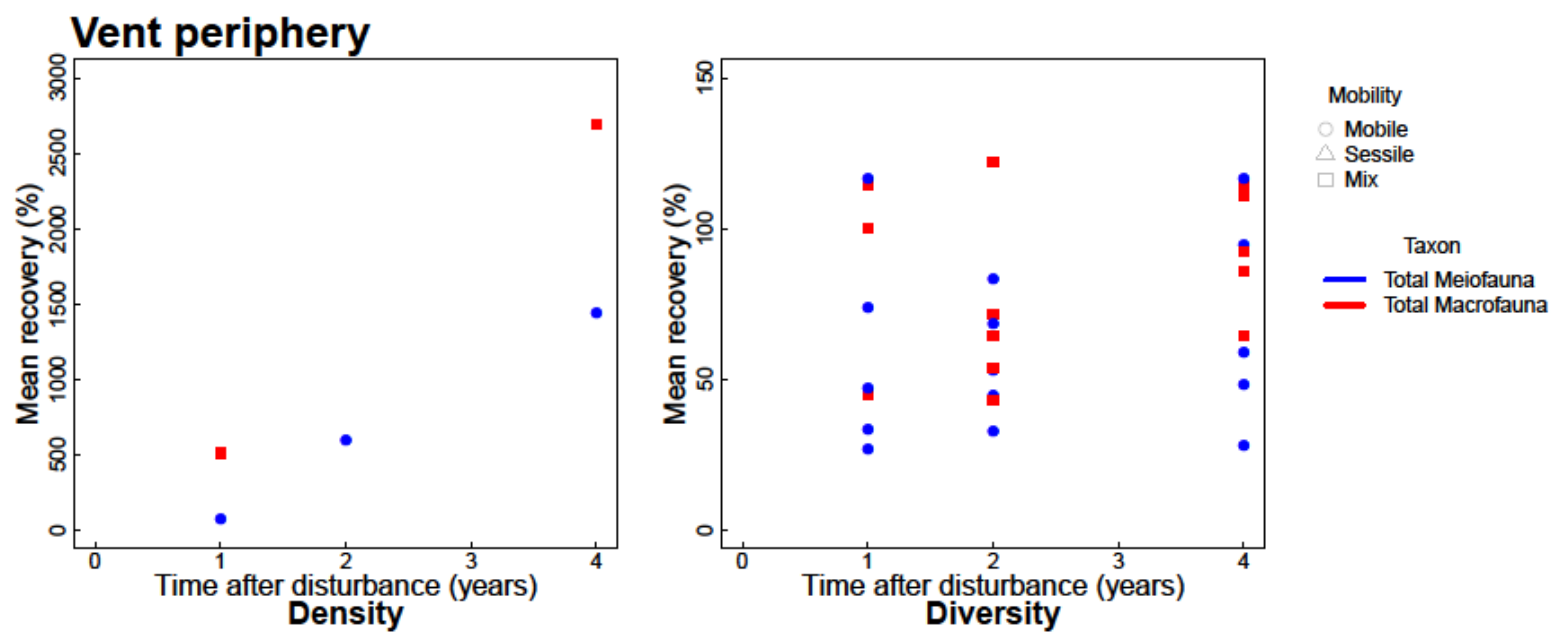
Fig. 8. Absolute numbers and standard deviation of density and diversity values measured predisturbance (indicated as P) and after disturbance (in years) for meiofauna and macrofauna in the vent periphery. For data and metric see Appendix A. Circles: mobile taxa. Triangle: sessile taxa. Square: mixed taxa (sessile and mobile).
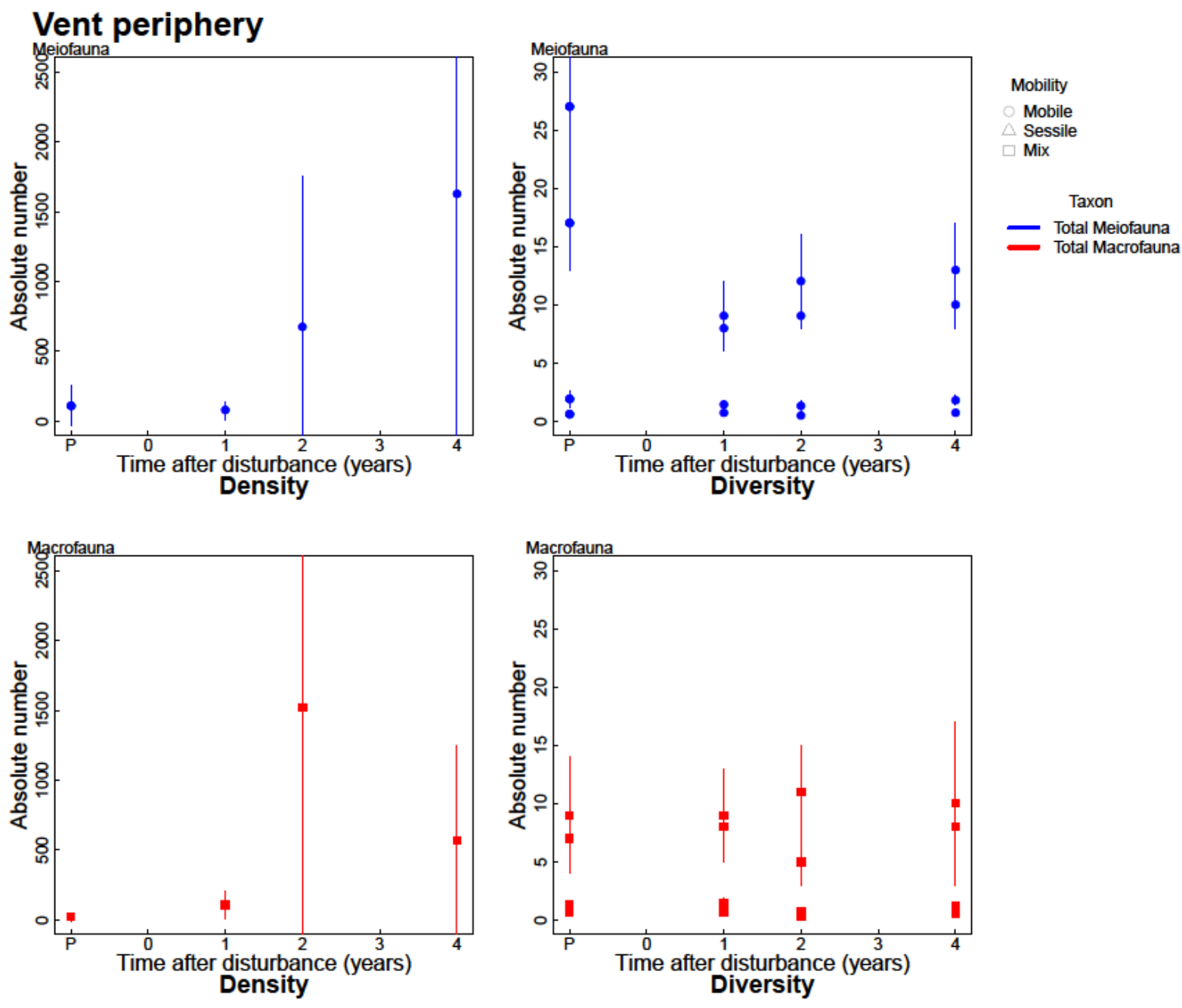
Fig. 9. Mean recovery (\%) relative to pre-disturbance megafaunal density and diversity at seamounts. For data see Appendix A. Aust: Australia. NZ: New Zealand.
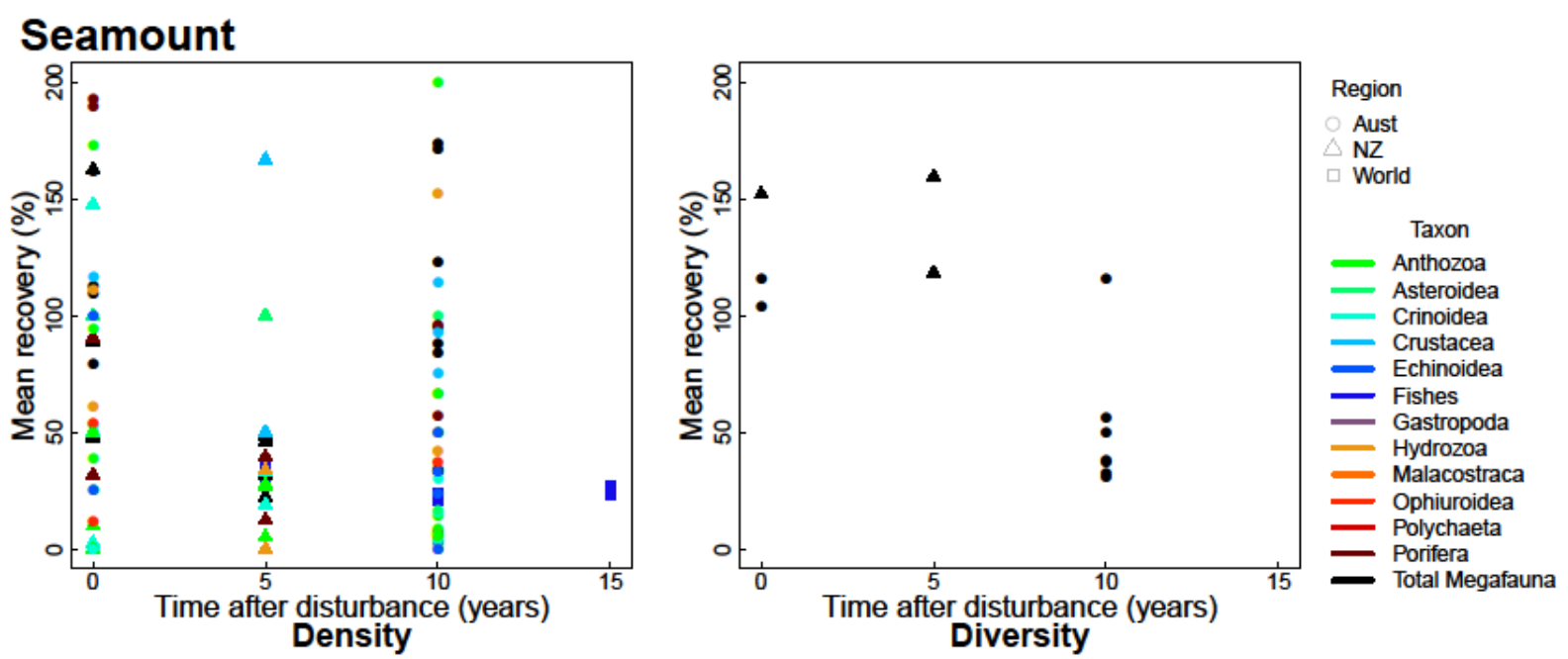
Fig. 10. Absolute numbers and standard deviation of density and diversity values measured pre-disturbance (indicated as $\mathrm{P}$ ) and after disturbance (in years) for megafauna at seamounts. For data and metric see Appendix A.
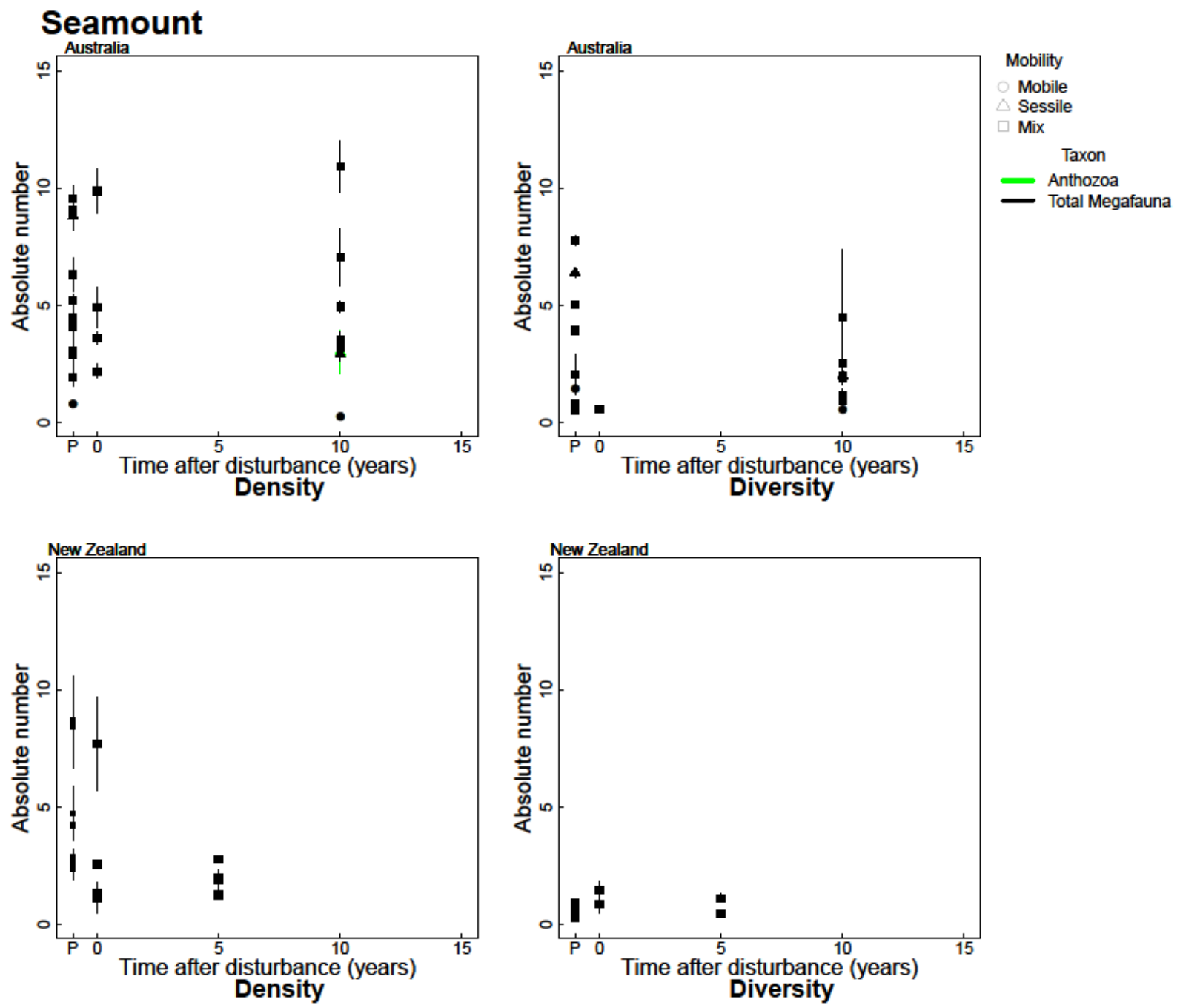
Fig. 11. Results of Wilcoxon rank sum tests for differences in mean recovery (\%) relative to pre-disturbance diversity and density for megafauna at seamounts. P-values are given for significant differences.

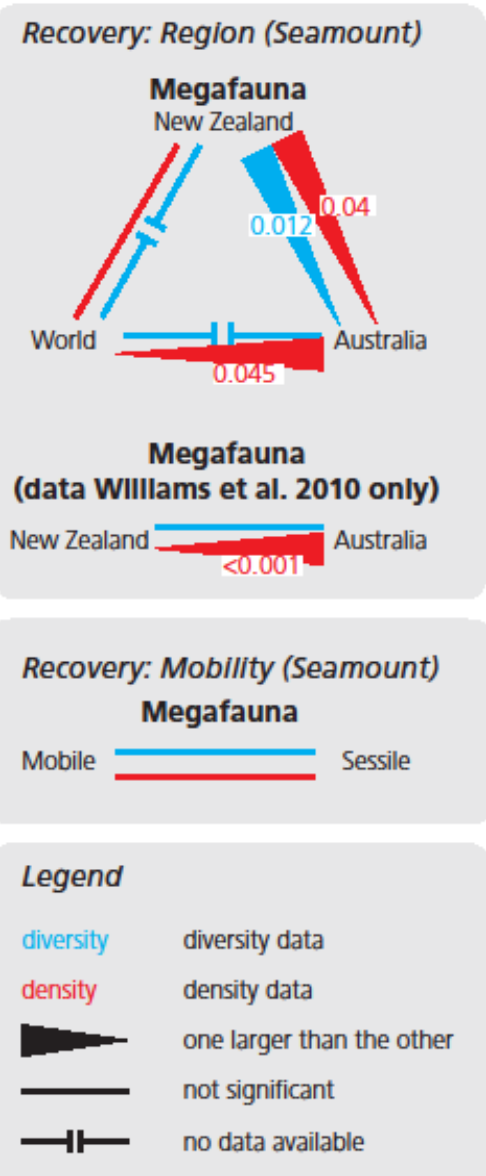


Fig. 12. Mean recovery (\%) relative to pre-disturbance faunal density and diversity at nodule fields. For data see Appendix A. CIO: Central Indian Ocean. CCZ:Clarion Clipperton Fracture Zone. DISCOL: "DISturbance and reCOLonization experiment" in Peru Basin.
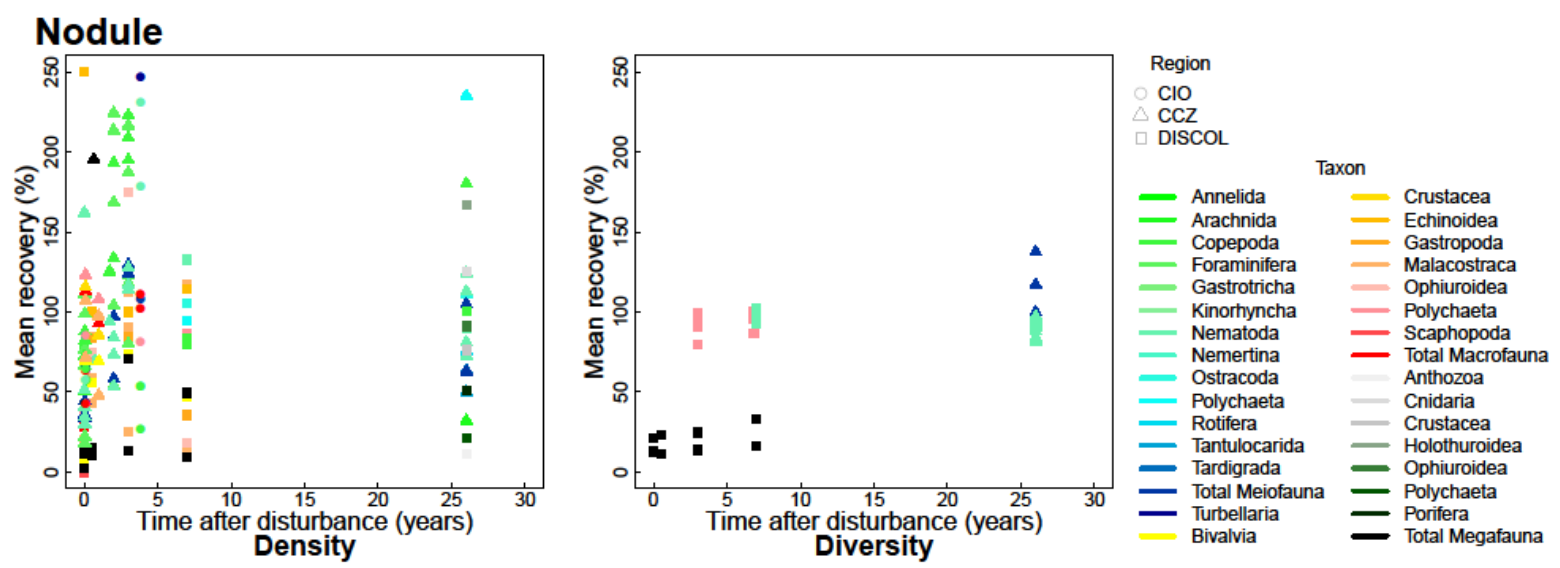
Fig. 13. Mean recovery (\%) relative to pre-disturbance faunal density and diversity at nodule fields. For data see Appendix A. Circles: mobile taxa. Triangle: sessile taxa. Square: mixed taxa (sessile and mobile).

\section{Nodule}

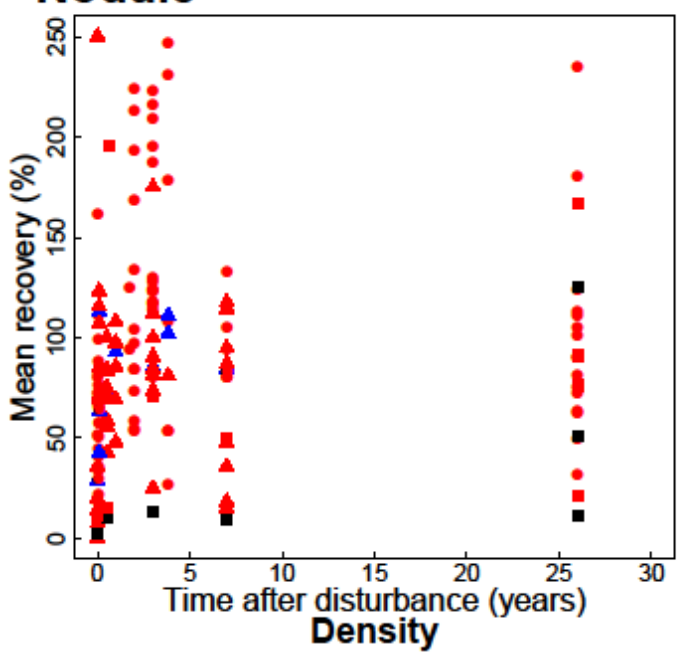

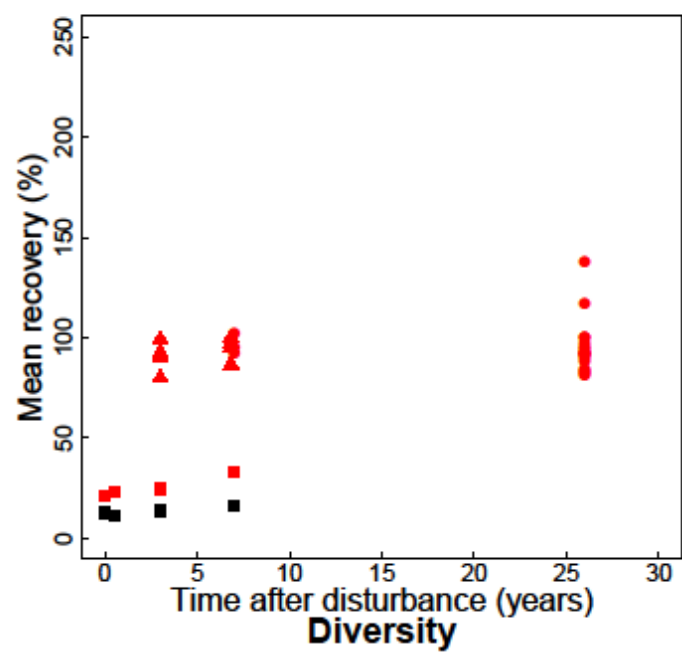

Size class

Meiofauna

Macrofauna

Megafauna

Mobility

Mobile

- Sessile Mix 
Fig. 14. Absolute numbers and standard deviation of density and diversity values measured pre-disturbance (indicated as P) and after disturbance (in years) for meio-. macro- and megafaun at nodule fields. For data and metric see Appendix A Circles: mobile taxa. Triangle: sessile taxa. Square: mixed taxa (sessile and mobile). ClO: Central Indian Ocean. CCZ:Clarion Clipperton Fracture Zone. DISCOL: "D!Sturbance and reCOLonization experiment" in Peru Basin.
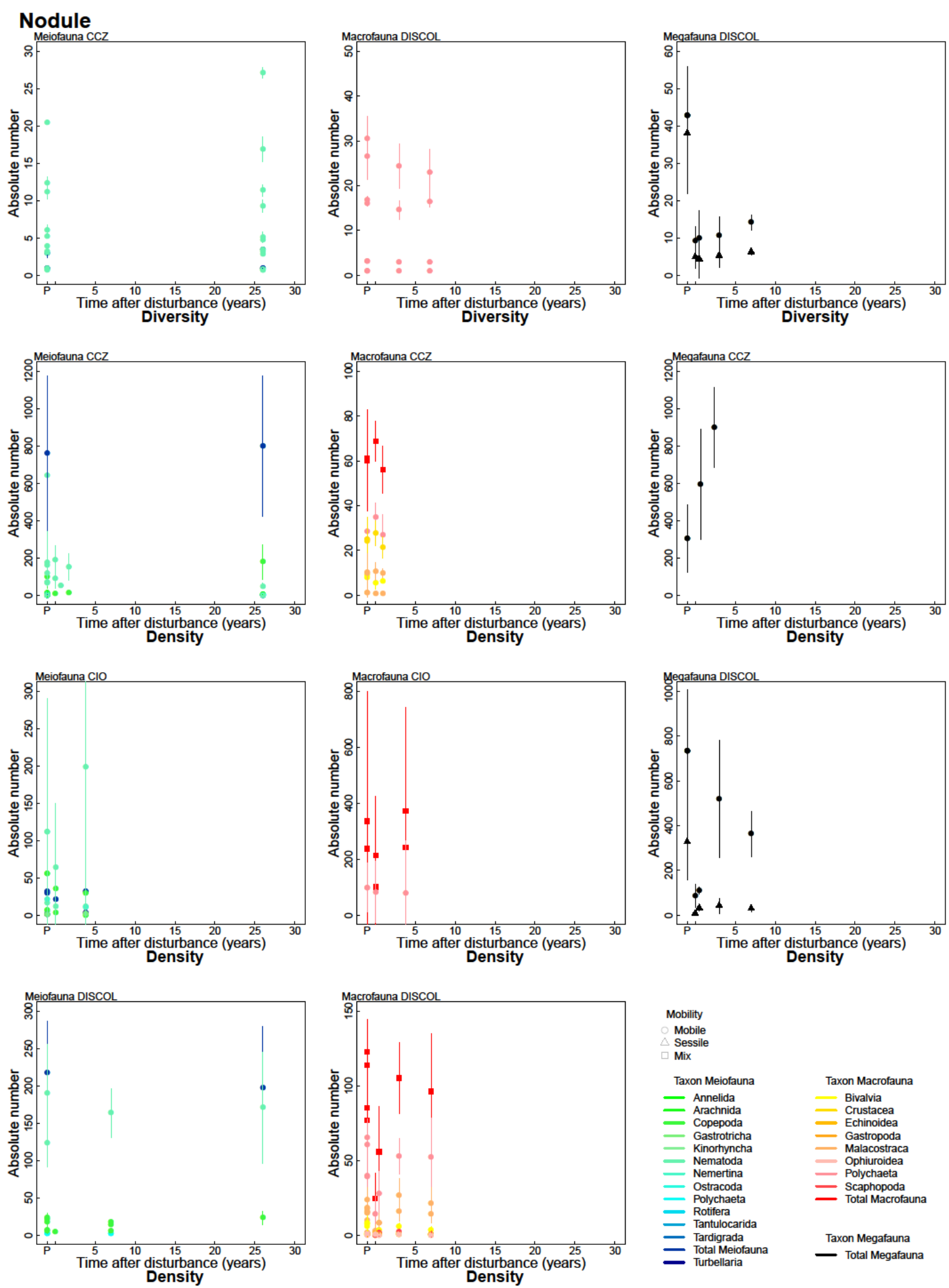
Fig. 15. Results of Wilcoxon rank sum tests for differences in mean recovery (\%) relative to pre-disturbance diversity and density between meio- and macrofauna at nodule fields according to region, size class and mobility. CIO: Central Indian Ocean. CCZ:Clarion Clipperton Fracture Zone. DISCOL: "DISturbance and reCOLonization experiment" in Peru Basin. P-values are given for significant differences.

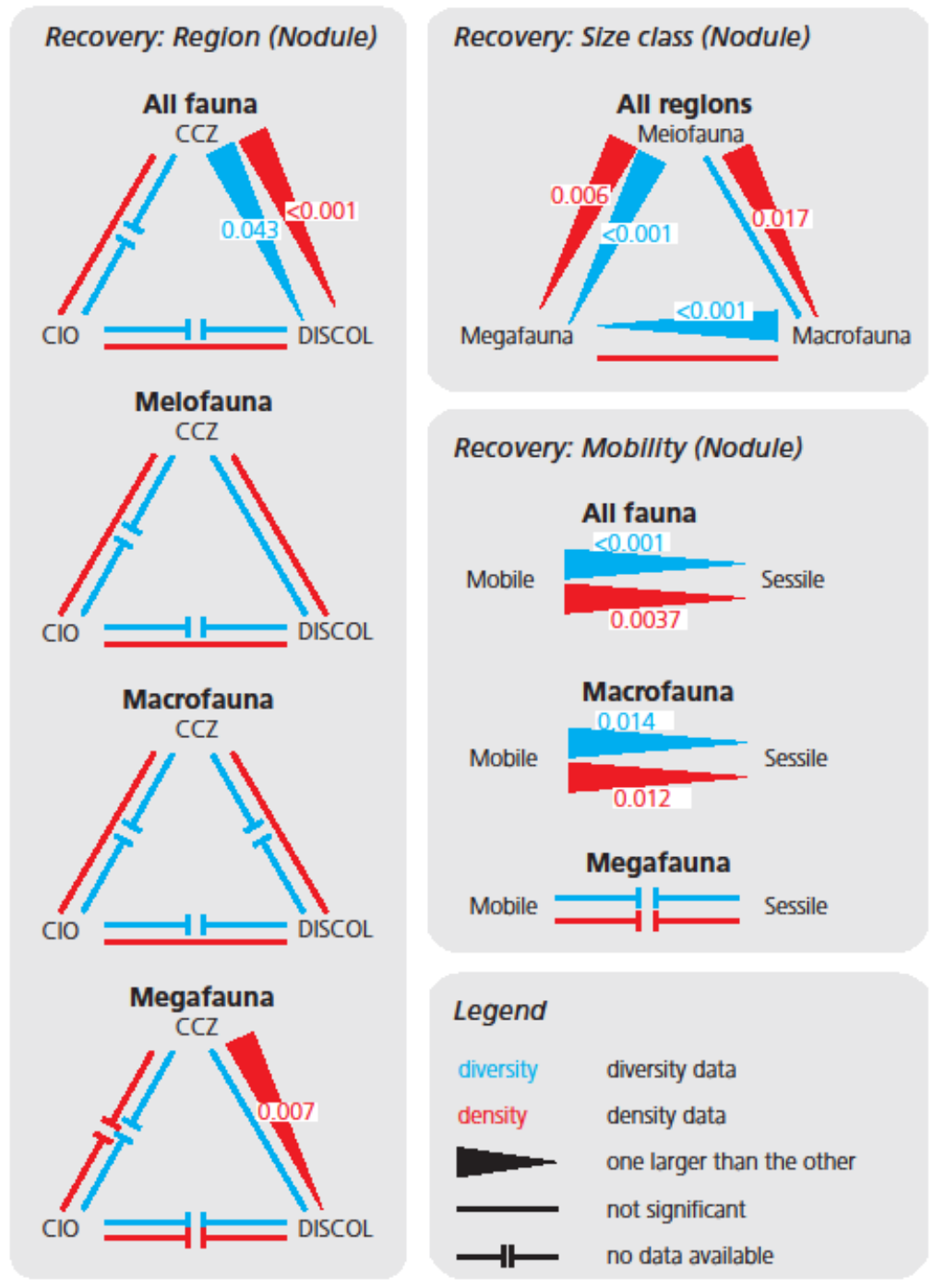


Fig. 16. Mean recovery (\%) relative to pre-disturbance faunal density and diversity at seamounts, active vents, vent periphery, and nodule fields. No recovery data were available for inactive vents. For data see Appendix A.

\section{All ecosystems}
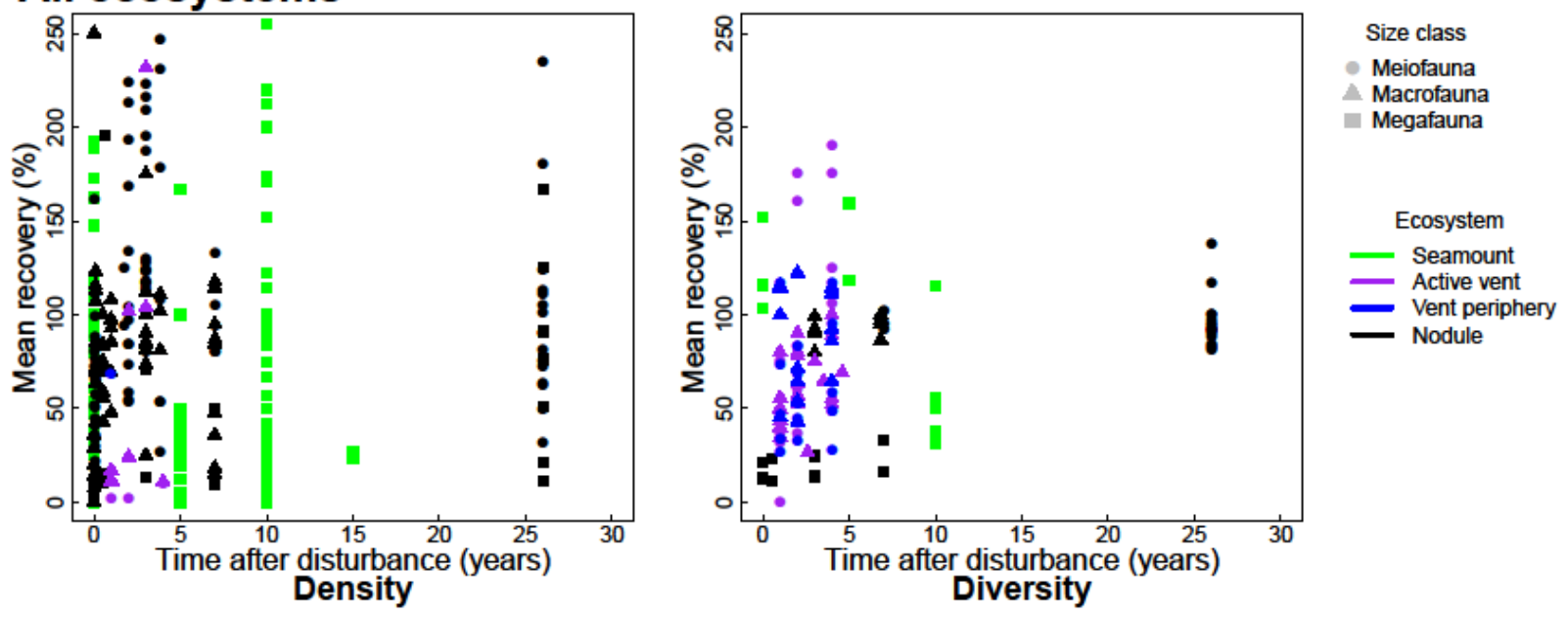


\section{Table}

\section{Table 1}

Short summary of main knowledge gaps and problem that currently hinder a precise prediction of resilience of benthic deep-sea fauna to mining activities, and potential solutions to diminish knowledge gaps.

\begin{tabular}{|c|c|c|}
\hline Knowledge gap & Problem & Potential Solution \\
\hline Mining operations & $\begin{array}{l}\text { Unknown spatial and temporal scale and nature of } \\
\text { mining operations }\end{array}$ & Provide expected scales and conditions of mining operations \\
\hline Sediment plumes & $\begin{array}{l}\text { Unknown scale of sediment plume (particle size, } \\
\text { toxicity, dispersion, temperature) }\end{array}$ & Provide expected scales and conditions of sediment plumes \\
\hline Recovery processes & $\begin{array}{l}\text { Observed recovery patterns are from small-scale } \\
\text { disturbance studies and different areas }\end{array}$ & Perform test-mining to investigate effects \\
\hline $\begin{array}{l}\text { Lack of methodological } \\
\text { standardization }\end{array}$ & $\begin{array}{l}\text { Lack hinders intercalibration of data sets even within } \\
\text { same regions }\end{array}$ & $\begin{array}{l}\text { Develop detailed standardized sampling protocols (sample number, size, area, } \\
\text { timeframe) }\end{array}$ \\
\hline $\begin{array}{l}\text { Lack of samples from parts } \\
\text { of license areas }\end{array}$ & $\begin{array}{l}\text { Impedes estimation of how representative existing } \\
\text { data are }\end{array}$ & Standardized sampling in license areas \\
\hline $\begin{array}{l}\text { Lack of samples from } \\
\text { potential protected } \\
\text { areas }\end{array}$ & $\begin{array}{l}\text { Impedes whether recolonization can take place from } \\
\text { designated preservation areas }\end{array}$ & Standardized sampling in potential protected areas \\
\hline $\begin{array}{l}\text { Faunal variability across } \\
\text { spatial and temporal } \\
\text { scales }\end{array}$ & $\begin{array}{l}\text { Difficulty to define pre-disturbance conditions and } \\
\text { monitor change }\end{array}$ & Standardized sampling before and after (test) mining, obtain long-term datasets \\
\hline $\begin{array}{l}\text { Undescribed species/lack } \\
\text { of genetic data }\end{array}$ & $\begin{array}{l}\text { Hinders comparison between data sets and } \\
\text { evaluation of species range sizes }\end{array}$ & Describe species including genetic codes (material deposits) \\
\hline $\begin{array}{l}\text { Biogeography and } \\
\text { endemicity of fauna }\end{array}$ & $\begin{array}{l}\text { Areas that may host source populations are often } \\
\text { unknown }\end{array}$ & Study biogeography and endemicity (also outside areas of mining interest) \\
\hline Limited taxon sampling & $\begin{array}{l}\text { Biased data on biogeography, connectivity and } \\
\text { recovery potential }\end{array}$ & Study species of different sizes and life traits \\
\hline $\begin{array}{l}\text { Reproductive biology and } \\
\text { settlement cues }\end{array}$ & $\begin{array}{l}\text { Larvae and adults likely respond different to stress } \\
\text { and disturbance }\end{array}$ & Study biology of species \\
\hline $\begin{array}{l}\text { Resistance of deep-sea } \\
\text { species to toxicity }\end{array}$ & $\begin{array}{l}\text { Resistance of deep-sea species to toxic plumes may } \\
\text { not be estimated based on shallow-water species }\end{array}$ & $\begin{array}{l}\text { Study effects of toxicity on deep-sea species and shallow-water species to determine } \\
\text { suitability of shallow-water taxa as ecotoxicological proxies for deep-sea taxa }\end{array}$ \\
\hline Cumulative effects & $\begin{array}{l}\text { Cumulative effects may reduce resilience and may act } \\
\text { synergistically }\end{array}$ & Consider cumulative effects \\
\hline
\end{tabular}

